Article

\title{
The Return to Europe or the Return to Solidarity? Gdańsk Shipyard-Case Study in Organizational Culture
}

\author{
Grażyna Prawelska-Skrzypek (D) and Agata Morgan *(D) \\ Faculty of Management and Social Communication, Jagiellonian University, 4 Łojasiewicza Street, \\ 30-348 Cracow, Poland; grazyna.prawelska-skrzypek@uj.edu.pl \\ * Correspondence: ad.morgan@data.pl
}

Received: 14 May 2020; Accepted: 26 August 2020; Published: 28 August 2020

\begin{abstract}
Objective: This paper is an attempt to give an analysis of the cultural impact of "Solidarity" on Polish organizational culture, and the process of substituting that message for an alternative one-neoliberal organizational culture.
\end{abstract}

Keywords: responsible management; solidarity culture; postcolonial theories; postsocialist space

\section{Introduction}

The focus of this study is solidarity culture as a fundamental part of Polish organizational culture after the year 1980 and its collision with neoliberal values, which were introduced in Poland during the transition process to a free market economy in the year 1989. Our research aims at investigating the role of organizational culture as a fundamental part of sustainable development in the Polish context.

A series of changes at the regional level in Poland and other countries of Central and Eastern Europe, such as the fall of communism, the introduction of a neoliberal market economy, and the inclusion of these countries into the European Union, influenced the transition from a cultural message of solidarity to one of very pronounced neoliberalism. In addition to the aforementioned changes, it is important to add the state-level changes, which included globalization and the development of media, digital media in particular, all of which could be classified as non-political influences. After 1989, Poland was the site of a collision between the two cultures, that of solidarity with the neoliberal one. The values of each of them were based on different values and convictions: the domestic culture of solidarity had been built around the labor union "Solidarity", and was based on cooperation and community, as opposed to the individuality and personal responsibility of neoliberalism [1]. As a result, two competing visions of society emerged: the official one, which was present in public discourse and media, and supported drastic economic change, individualism, and entrepreneurship; the other-unofficial, focused on communities and solidarity, and mostly popular amongst the working class, which was excluded from the public discourse and present predominantly in oral tradition [2].

As a symptom of a deeper conflict of ideas, in the year 2018-2020 arose an argument around the symbol and legacy of Solidarity (the logo, the board with the 21 postulates), between the European Solidarity Centre (an institution designed to spread awareness about the legacy of "Solidarity") and the Independent Self-Governing Labor Union "Solidarity". The conflict is physically taking place in Gdańsk, particularly in the old Dockyard area, but it is clearly visible in the traditional media and even on social media. From the available materials, we got the impression that the conflict is centered around symbols but appeals to deeper values of culture. We decided to carry out a field study at the place of the conflict. Our goal was to conduct empirical research in the public domain, which has become a symbol in itself, and further, to better understand the changes in Polish organizational culture. 
We were primarily interested in researching culture as "the foundation of sustainable development that coordinates and integrates activities within this area, or rather the intangible dimension that refers to the basic principles, beliefs, and values" [3]. Cultural heritage items perceived as tangible, material artefacts were analyzed in our paper as cultural symbols representing certain beliefs and values, as opposed to the perspective of the growing consumption of cultural heritage goods and services, which is typical for cultural tourism development studies.

This article is an early analysis of the collision between solidarity culture and neoliberal culture, in the form of a case study of the Gdańsk Shipyard —-the cradle of the "Solidarity" movement. At the same time, it is an inquiry into organizational culture in a wider context; we choose not to concentrate on the organization culture of a particular company (the Shipyard), but on organizational culture as a part of national culture, as proposed by Geert Hofstede [4].

We have tried to find answers to two research questions: RQ1: How has the process of replacing the culture of Solidarity with neoliberal culture undergone in Polish organizational culture? RQ2: How does the new hybrid form of this culture look in the widely understood public domain around the Gdańsk Shipyard? As part of the research we analyzed cultural messages, which appeared on the grounds of the Gdańsk Shipyard (field research on the property belonging to the Shipyard, analysis of the discourse around the Shipyard in mass media, analysis of pictures and artistic works, and in-depth interviews). We were inquiring, from a postcolonial perspective, the present shape of Polish organizational culture and its sustainability, with the use of concepts such as hybridity and cultural mimicry authored by Homi. K. Bhabha [5]. Postcolonial theories, however unpopular in organizational culture research, served us as a basic tool for analysis according to Bourdieu's postulate. Bourdieu argued that theories derive more from a confrontation with constantly new empirical facts, rather than confronting other theories [6].

This article consists of the following parts: a theoretical introduction to the postcolonial theories and the theory of cultural hybridity covering the state of research within management and organization studies as well as a theoretical framework for the Polish culture of solidarity. Subsequently, we present the methodology of the research that was conducted on the premises of the Gdańsk Shipyard, which aims at investigating the role of culture as a fundamental part of sustainable development in the Polish context and its results. The following part discusses empirical data organized around the two aforementioned research questions. The summary includes conclusions regarding hybridity and cultural mimicry of Polish culture, which allowed the preservation of solidarity culture during the process of substituting it for neoliberal organizational culture within the transition to a market economy.

\section{Theoretical Background}

\subsection{Sustainable Development}

Although a variety of definitions have been conferred on the concept of sustainable development [7], the most widely accepted definition, provided by the Brundtland Report, states that "sustainable development is development that meets the needs of the present without compromising the ability of future generations to meet their own needs" [8] (p. 16). It is a broad definition focusing on intergenerational equity and it provides an interesting perspective for researching culture as a pillar of sustainable development. This definition does not focus on separation between economics, politics, ecology, and culture since many social practices from all four pillars are interrelated.

Finding an acceptable definition of culture seems to be a more difficult task, especially in terms of sustainable development and the needs of future generations. In 1871, the anthropologist Edward B. Tylor in his book Primitive Culture defined culture as "that complex whole which includes knowledge, beliefs, art, morals, customs, and any other capabilities and habits acquired by man as a member of society" [9] (p. 43). This definition stresses the concept of acquired or learned behavior within the group as well as broad scope of activities constituting the meaning of culture. It is a simple, nonselective, and nonevaluative definition, and in many ways, a very modern one. However, it is a fixed definition, 
which does not include modern variables such as the impact of globalization or time, which influence the customs and art of almost all societies. Tylor's understanding of culture has been developed and extended by various authors, among others Ruth Benedict in Patterns of Culture (1934) and Margaret Mead in Coming of Age in Samoa (1928) and her other books. They both argued that human behavior is produced by cultures rather than determined by biological nature, therefore, establishing ground for the idea of "cultural determinism" - the key concept of anthropology for decades. However, Benedict and Mead both refrained from a detailed description of cultures (as their mentor Franz Boas from the Columbia University used to do); instead, they went further, attempting to make a typology of cultures, which seems to be quite controversial from the present point of view. Every typology focuses on distinctions and on drawing boundaries, and it directs research towards endemic cultures or their remains to be analyzed within a Western frame of discourse. Such academic approach, based on a search for disparities, seems outdated. Ruth Benedict in her work expressed a belief that customs from each culture had a meaning to the people who lived in them, therefore, they should not be dismissed or trivialized or even judged by one's standards. Yet, at the same time, when researching the cultures of Native Americans, she used the Nietzschean opposites of "Apollonian" and "Dionysian" to describe differences between the cultures of two tribes [10], which is a clear example of setting a Western frame of discourse when analyzing indigenous cultures. Over the past four decades, during the time of "the cultural turn" in humanities and social sciences, the narrower use of culture to refer to the meanings of objects and events has gained popularity among academics. Clifford Geertz, a leading figure in the cultural turn, in The Interpretation of Cultures (1973) examines the discourses we use to interpret events and objects and give them meaning. There is a noticeable shift in emphasis toward meaning and away from a positivist epistemology [11].

\subsection{Postcolonial Theories}

This shift of interest towards a meaning and a discourse is one of the core issues of postcolonial theories, specifically the questioning about discourse and related questions regarding the production of knowledge within colonial power. Michael Foucault's discussions of the relationship between power and knowledge has influenced postcolonial critiques in explaining the discursive formation of colonialism, particularly in Edward Said's work Orientalism: Western Conceptions of the Orient [12]. Postcolonial discourse deconstructs the Western perceptions and representations of the non-West seen as Otherness. The colonial discourse represented the West and non-West in a binary, asymmetrical way, where the Western model of social relations was described as better, civilized, developed, and scientific as opposed to the worse, barbaric, backward, and immoral non-West. Postcolonial discourse deconstructs Western understanding and representation of the non-West as Otherness, granting individual countries and cultures the right to autonomous self-identity and self-definition. In the 1990s, Homi K. Bhabha, a leading voice in postcolonial theories, developed an interesting, although controversial, theory of cultural hybridity, which questions the belief that culture defines its limits through exclusion [5]. Bhabha argues for hybridity and mimicries of cultures, claiming that hybridity results from various forms of colonization, which lead to cultural collisions and interchanges. This hybrid trace contradicts the attempt to fix and control indigenous cultures. Bhabha describes postcolonial cultures as mixing cultural and linguistic imitation of the colonist with pre-existing traditional customs. We would like to adopt postcolonial theories and the theory of cultural hybridity as a theoretical framework for our investigation of the Polish culture of solidarity, which after the year 1989 (and the collapse of the communism) was shaped by the Western political and economic system in the process described as "transition to market economy".

\subsection{Postcolonial Theories in Management and Organization Studies}

Postcolonial perspective is not represented or perhaps, more precisely, it is only marginally represented in management and organization studies, as it was broadly discussed by two Australian researchers Gavin Jack and Robert Westwood [13], even though a significant number of Western and 
especially American organizations are relocating, along with their typical organization methods, to non-Western countries with lower labor costs. It is possible that management and organization studies more eagerly accept Western concepts (work organization, accounting methods, organization of social relations in the workplace and elsewhere) as general norms and therefore, they are not questioned or subjected to critical reflection. Those researchers point out, inter alia, that the dominant scientific discussions in management and organization studies take place in the most prestigious English language scientific journals with the use of theoretical structures and measurement scales typical of the West, thus, limiting the framework of this discourse [14]. There are strong links between the English language, accepted terms setting the frame of a discourse, and excluding postcolonial perspective and embodied experiences of subaltern groups. Yet, there is also another side of this phenomena. Some scholars, mostly of Eastern European origins, have explored structural homologies between postcolonial and postsocialist spaces, where the 'post' in the 'postsocialist' and the 'postcolonial' signify the material, social, and political realities that were formed in the wake of crumbling empires-either capitalist-colonial or Soviet-socialist [15-18]. They highlight the specific character that imperial domination has taken in the region, in which there is a clear tendency towards "self-colonization" in relation to the West; this phenomenon goes a long way in explaining why in East Central Europe, the Western model of economic and social development (in its most libertarian forms) reigns uncontested. Self-colonization is a concept due to Alexander Kiossev, with which he describes countries that gave in to Europe and the West, because of their cultural advantage, even if they were not de facto conquered and turned into colonies. In his opinion, countries of Central Eastern Europe and the Balkans found themselves at the peripheries, and consequently, after realizing the cultural dominance of the West, voluntarily, with the help of local elites, began internalizing the basic values and norms of imperial Europe. The local culture was viewed as "the culture of lacking" and the focus was on catching up, filling in, and enlightening the nation through the implementation of Western solutions [19].

In Polish academia, postcolonial theories are discussed in literary studies and in history, while in Polish management and organization studies, they remain marginal. During the initial period, rare studies conducted from a postcolonial perspective focused on linguistic analysis of management practices in Poland after 1989 and on the observed domination of English language [20]. This is quite typical for postcolonial theories, which originate from and flourish in literary studies worldwide and very often concentrate on language [21-24]. Monika Kostera offered an interesting perspective in the spirit of postcolonialism, though using a different metaphor and terminology, when naming the massive arrival of Western market economy experts to Poland in the 1990s "a modern crusade", which was aimed at converting Polish society to real capitalism after a period of socialism [25]. A more recent voice presenting postcolonial positions in Polish management and organization studies is seen in the article by Gregory Allen [26].

\subsection{Neoliberal Economic Solutions in Postsocialist Countries}

Solutions that were widely accepted and thoroughly tested in the West, in their most neoliberal forms, were implemented in the sectors of economy and social relations by many countries of Central and Eastern Europe, including Poland. Most researchers and politicians described the changes as the only possible ones, noting the requirements set by financial institutions such as the International Monetary Fund (IMF) and the World Bank, from which the economies of many countries depended, in particular, on their credit line [27]. The solutions were named jointly as the Washington consensus, created in cooperation with the IMF and the World Bank, and included ten directives that laid out the neoliberal model of economic development [28].

One of the key rules of the Washington consensus was the supposition that the government under any circumstances should not intervene in the job market, since that would destroy the natural process of improving productivity and hurt competitiveness. It may be best described as the logic of belt-tightening, interconnected with the logic of delayed gratification present in Central and Eastern European countries since the fall of communism. In Poland, it resulted in a high unemployment rate 
i.e., in 1993 the unemployment rate reached $16.4 \%$. Polish society was simply not prepared for a shock of this magnitude. The Polish government departed from the suggestions of the consensus and the radical reform program. The initial stabilization of the job market took place in 1994 as a result of slowing down restructuration in certain industries. After 1998, the unemployment rate was $10.4 \%$ and began rising again because of privatization contracts between companies and the government expiring. The contracts signed in the 1990s specified that the companies must maintain employment at a certain level. Once the contracts expired, the companies undertook massive job cuts, and consequently, in the years 2002-2003, unemployment reached a record high of 20\% [29]. This example demonstrates that moving away from the rules of the Washington consensus not only did not cause any negative economic consequence (and in the relations with financial institutions), but allowed the country to save jobs, giving society time to adapt to the new rules.

The solutions of the Washington consensus were often criticized by experts within the institutions supporting them. In 1999, Joseph Stiglitz, one of the leading economists and the vice-chairman of the World Bank, blamed international institutions and advisors for forcing their own one-sided visions of politics in countries undergoing transformation, which made the already difficult economic situation worse. He argued that the reforms based on the Washington consensus put the countries of Central and Eastern Europe at greater risk, of which the brunt was carried by those least capable of dealing with it [30]. Another criticism of the solutions came from Justin Yifu Lin (also a vice-chairman of the World Bank), but he went further by claiming that the Washington Consensus reforms resulted in economic collapse and stagnation in many transition economies [31,32]. Elizabeth Dunn observed that: "The basis for the Polish transition was a belief that a change for better requires becoming more like Western Europe and the United States. The idea of convergence or of the 'return to Europe' became the main metaphor for the post-socialist transformation" [1] (p. 230).

\subsection{Culture in Organizational Studies}

Culture is an important term also for management and organizational studies, especially from the point of view of increasing globalization and global expansion of business and other organizations. In 1980, Greet Hofstede published his widely quoted work Culture's Consequences: International Differences in Work-related Values, introducing four dimensions of culture from a managerial point of view: power distance, individualism versus collectivism, masculinity versus femininity, and avoidance of uncertainty [33]. His findings were extended by other researchers (with Hofstede's endorsement) within cross cultural management studies, such as Michael $\mathrm{H}$. Bond, who added another cultural dimension-Confucian dynamism—explaining differences between data from Far Eastern and Western countries as differences in long-term and short-term orientation of cultures [34]. They were even further expanded by Michael Minkov, who came up with the sixth cultural dimension, also accepted and adopted by Hofstede himself-indulgence versus restraint—related to the gratification versus control of basic human desires to enjoy life [35,36].

In 1991, Hofstede expanded on his idea in the book Cultures and Organizations: Software for the Mind, claiming that the differences between national cultures are deeply rooted values of the particular cultures. Cultural values may develop the way in which people expect that companies will be managed and how the relations between the leaders and the followers should look like. This leads to a difference in expectations between the employer and the employees, even if the workers accept certain ways of conduct imposed by the company. Hofstede presented culture in a way similar to an onion, at the center of which there are values, and rituals, heroes, and symbols formed the following layers. Rituals, heroes, and symbols were labelled as cultural practices, whereas values were treated as its elementary characteristics that allowed the differentiation between good and evil, morality and immorality, normality and abnormality. This research-backed observation that Hofstede made became the starting point for our analysis of the collision of solidarity culture with Western neoliberal culture; it has also set the framework of definitions within which we will operate and attempt to understand organizational culture. As Hofstede has pointed out: Effective shared practices are the reason that 
multinational corporations can function at all. Employing personnel from a variety of nationalities, they cannot assume common values [4] (p. 348).

Hofstede's model is generally accepted and perceived as a theoretical model, which increases our sensitivity to cultural differences. However, critics representing postcolonial positions point out its Western orientation, as described by Dennis Kwek “( . . ) Hofstede's theorizations need to be understood as cultural products of a Eurocentric mindset. Hofstede's scholarly contributions, moreover, must be viewed in the context of the historical power-relationships that existed between East and West during colonialism, which allowed the East to be defined by the West" [37] (p. 161).

\subsection{Polish Organizational Culture after the Year 1989}

None of the culture dimensions described by Hofstede fully apply to a society undergoing "a shock therapy", as was the case with Polish society in the 1990s, when hyperinflation reached 500 percent annually and unemployment rate was 20 percent. People from all social groups could no longer count on their previous understanding of how the world works, what to think, and what to feel about individualism versus collectivism or any other dimensions of culture. As Katherine Verdery observed:

"Students of the demise of Soviet-style party-states have tended to pose the problems of post-socialist transformations as creating markets, making private property, and constructing democracy. ( . . ) I believe the post-socialist change is much bigger. It is a problem of reorganization on a cosmic scale, and it involves the redefinition of virtually everything, including morality, social relations, and basic meanings. It means a reordering of people's entire meaningful worlds" [38] (pp. 34-35).

During this radical change in the political, economic, and moral systems, represented by the symbolic date of 1989, Poland, like other Eastern European countries, faced equally radical change in its organizational culture. It was a process of accelerated transition from a culture where socialist workplaces were considered public ownership to a culture based on private property, for example, property acquired by a foreign investor. Polish employees and management had to develop a completely new conceptualization of employment relations, while in many cases, staying in the same surrounding, in the same factory. It was particularly difficult for employees of large companies, where workers used to have a significant voice in decision making processes because communist authorities from the year 1980-marking the rise of Solidarity labor unions-were afraid of strikes and workers' protests. In the market economy system, and particularly in its neoliberalism and dismissiveness towards the labor unions model, workers were marginalized. The subsequent restructuring with its redundancies reduced employees' autonomy, job security, and bargaining power. Before 1989, the majority of Polish society was aware of the gap between the theory and the daily operations of the socialist system and looked forward to a market economy. In a short period of time, it became clear that their concepts about capitalism were naïve and different from the neoliberal reality they had to face.

Elizabeth Dunn, an American anthropologist, who between 1995 and 1997 was working and conducting field research in the Alima-Gerber factory in Poland, introduced a metaphor of marriage when describing the privatization process of the Polish company Alima by the American company Gerber [1]. This metaphor was used by Alima's employees and the national press [1] (p. 218). Dunn investigated the transition process in Polish organizational culture through a study of workers and changing management techniques at the Alima-Gerber factory in Rzeszów, Poland, formerly a state-owned enterprise, which was privatized by the Gerber Products Company of Fremont, Michigan. As she pointed out, Polish workers conceptualizing their employment relations used a metaphor of kinship, in order to 'keep the distinction between people and things, preserve the priority of work over capital, be constituted as subjects rather than objects of work, emphasize that they are people and not assets' [1] (p. 226). They tried to find a third way, which does not alienate labor from capital. Although she noticed that Americans understood neither the intention nor symbols used by Poles, for them, labor was simply another good-“anonymous and general commodity, like money" [1] (p. 225). 
At the same time, Dunn refused to see the conflicts occurring between workers and managers in Alima-Gerber as a form of resistance linked to Solidarity heritage and she saw this perspective as tempting but not adequate as an explanation for labor disputes [1] (p. 227). At this point, we cannot agree with Elizabeth Dunn's opinion, although her observations are insightful and important. Rejecting solidarity in resistance as the cause of labor disputes, Dunn turns to the metaphor of kinship, in which Alima's workers were cast as "wife" or "child" and follows with its deeper interpretation. As she believes, it was workers' recognition and expression of their submissive position: "To become the 'wife' to a multinational corporation is to continually acknowledge-and accept-the unequal distribution of power" [1] (p. 227). Dunn's interpretation can be reversed or altered if we assume that Alima's workers might conceptualize their role through the lens of Catholic social teaching, which was a strong source of inspiration for the Solidarity movement. In this Catholic social doctrine, one of the main principles is human dignity. Full human development takes place in relationships with others. The family is the first and fundamental unit of society. Together, families form communities, communities a state, and together, all across the world, each human is part of the human family. It is understandable that Alima's employees, living in Rzeszów-one of the most Catholic areas in Poland—might choose a ready-made church metaphor of kinship to conceptualize and describe their new situation in a privatized company during a disturbing period of sudden political, economic, and social changes.

In retrospect, one may think that workers' conceptualization allowed for the inclusion of Solidarity heritage into a new Polish organizational culture after the year 1989. Dunn observed various attempts by Polish workers to introduce particular organizational practices during the initial period of privatization. One of the most inspiring is a job evaluation practice interpreted by Agata Morgan:

“(Dunn) was investigating how neoliberal management practices sought to remake workers as individuals of varying qualities-and how workers resisted it. She reported various interesting strategies of resistance used during the process of privatization. Although they were not successful at the time, nevertheless they show other possibilities for organizing more ethical work relations. One of the adopted strategies is particularly striking-middle managers refused to consider the work efficiency of a particular person as the only factor in the evaluation process during redundancies. Instead, they tried to assess the family situation of each employee, taking into consideration sources of income of the other members of the worker's family and the worker's ability to face unemployment. They were not promoting a lack of work ethic but simply trying to perceive their workmates as part of a wider community, not only as a replaceable labor force, and took under consideration workers' responsibilities toward dependents. This may be described as an attempt to include ethical choices in the job evaluation process, while making sure that all members of the community are provided with some support" [39] (p. 156).

\section{Research Methods}

\section{Research Questions and Methodology}

After thirty years of a neoliberal economic system in Poland, we have decided to check what Solidarity cultural heritage looks like in the cradle of the "Solidarity" movement at the Gdańsk Shipyard. What has stimulated our interest was an argument around the symbol and legacy of Solidarity (the logo, the board with the 21 postulates), between the European Solidarity Centre (an institution designed to spread awareness about the legacy of "Solidarity") and the Independent Self-Governing Labor Union "Solidarity". The conflict is physically taking place in Gdańsk, particularly in the old Dockyard area, but it was and still is clearly visible in the traditional media and even on social media. From the available materials, we got the impression that the conflict is centered around symbols but appeals to deeper values of the national organizational culture. We decided to carry out a field study at the place of the conflict. We opted for qualitative research, in line with a generic definition provided by N. Denzin and Y. Lincoln: 
"Qualitative research is a situated activity that locates the observer in the world. Qualitative research consists of a set of interpretative, material practices that make the world visible. These practices transform the world. They turn the world into a series of representations, including fieldnotes, interviews, conversations, photographs, recordings and memos to the self. At this level, qualitative research involves an interpretative, naturalistic approach to the world. This means that qualitative researchers study things in their natural settings, attempting to make sense of interpreted phenomena in terms of the meanings people bring to them" [40] (p. 3).

Our goal had been to conduct empirical research in the public domain, which has become a symbol in itself, and further, to better understand the changes in Polish organizational culture. From the two main approaches to empirical research-explorative and confirmative-we have chosen an explorative research, starting without any hypothesis (unlike in confirmative research). The aim of our empirical research was to widen and deepen knowledge of the chosen area, which in our opinion, was/is underexplored. We wanted to draw conclusions on the basis of newly acquired data.

We posed the following research questions:

RQ1 How has the process of replacing the culture of Solidarity with neoliberal culture undergone in Polish organizational culture?

RQ2 How does the new hybrid form of this culture look in the widely understood public domain around the Gdańsk Shipyard?

Our main research method was a case study, which can be understood and implemented differently. In the methodology adopted by us, this is an in-depth study of the complexity of the chosen phenomenon, allowing us to obtain its multi-faceted understanding. It is an interpretative approach, based on an attempt to understand individual and shared social meanings of the phenomenon/symbol. Various research methods are used in order to check whether they lead to the same conclusions [41].

Our research methods included: field observations, namely two study visits in Gdańsk with living arrangements on the premises of the former shipyard, and photographic documentation of the area. Visual ethnography and arts-based research also played an important role in our data gathering. Arts-based research is based on the conviction that our understanding of social reality is more complex than that provided by a scientific discourse. Through art, we notice connections that might not otherwise be seen, so our attention is called to other possibilities beyond those resulting from reading or talking about an issue or a problem. Our research into the culture of solidarity in Polish organizational culture began with art, i.e., a mural, which presented the stories of shipyard workers in a very simple aesthetic form. These were very moving autobiographies collected by visual artist Iwona Zajac and between the years 2004 and 2012, they were presented on the wall around the Gdańsk Shipyard. This mural and the workers' statements (currently only existing in virtual form) have become important research material.

During our trips, we conducted six in-depth interviews with: an engineer and a former employee of the Gdańsk Shipyard, an expert urban policy researcher, 2 employees of the European Solidarity Centre, and a visual artist (2 interviews) involved in a long-term artistic project based on the biographies of former shipyard workers. These were in-depth, non-standardized, open interviews, which lasted from 1 to $3 \mathrm{~h}$. We tried to get to know the opinions of the respondents about changes in the Polish organizational culture without suggesting any position. In selecting interviewees, we concentrated on two groups. The main group included people who used to work in the shipyard and were strongly connected with it, and we were interested in those who thrive in the new economic and social reality, as well as those who feel like they have lost part of their lives. We conducted an interview with a former shipyard's employee, an engineer who currently runs his own company. Unfortunately, the families of former employees whose lives were not as successful did not want to talk to us. We were able to observe these people in various social situations (shop, pharmacy, backyard meetings) and take advantage of the biographical interviews collected by Iwona Zając. The conducted interviews 
were recorded, listened to, and analyzed. In our analysis, we used both our original interviews as well as interviews conducted by a visual artist with actual shipyard workers during her artistic project. The interviews allowed us to obtain a wide scope of information ensuring better understanding of the research problems.

Over the course of two study visits to the Gdańsk Shipyard, the researchers stayed in rented flats located within the area of the former shipyard: in 2018, it was a modern apartment in a newly built, high apartment building on Wałowa Street, one of the Young City developments. In 2019, it was a flat in a rundown hundred-years-old, red-brick building, which was initially built for workers and located on Jana z Kolna Street. We were interested in staying in different places reflecting different situations of transformation of the examined space: old residential buildings, inhabited by families of former shipyard workers versus new apartment buildings built in place of former shipyard sites. The location gave us immediate access to a partly ruined old shipyard area, which recently became a monument of history, as well as to other areas still in use but undergoing various transformations, with new facilities-the European Solidarity Centre, local shops, and the pharmacy serving as a meeting place for old and new residents.

Our research was supplemented with analysis of the literature, press, and documents.

\section{Gdańsk Shipyard-A Case Study}

\subsection{Historical Background}

\subsubsection{History of the Gdańsk Shipyard}

The Gdańsk Shipyard is one of the most powerful contemporary Polish symbols. For years, it was a large state-owned shipyard in the Baltic seaport city of Gdańsk under communist-controlled Poland, established on the premises of the former German shipyards: Jana Klawitter's Shipyard (since 1804), then Kaiserliche Werft Danzig Shipyard (since 1844), and finally, Schichau Shipyard (since 1890). After the Second World War, the shipyard was called the Gdańsk Shipyard. From 1967 to 1989, the name of the shipyard was changed to the Lenin Shipyard (Stocznia Gdańska im. Lenina). Today, the shipyard is called the Gdańsk Shipyard SA (Stocznia Gdańska SA). It used to be a large industrial organization, for decades employing thousands of people, e.g., 16,295 employees in the year 1974, which was the highest employment level in its history [42] (p. 384). On 1 January 1990, Gdańsk Shipyard was transformed into a shareholder company (Stocznia Gdańska Spółka Akcyjna) with a large share belonging to the Treasury (approx. 60\%) and the shipyard crew (approx. 40\%). The company tried to adapt to the new economic system, but failed to modernize the production process, although, as Ost noted, it was an extraordinary difficult task of the "shock therapy", in which enterprises themselves were to finance the entire transformation process and adaptation to a new economic reality, although their owner was the state [2]. On the other hand, the number of employees increased-from 7452 in 1990 to 8955 in 1993 [42] (p. 392). The loss of the Soviet market and an inability to compete in the world market resulted in staggering financial setbacks in the company.

In 1996, the Gdańsk Shipyard went bankrupt as the very first of the big state-owned firms to go bankrupt after 1989. The shipyard workers demanded a restructuring plan from the Polish government but without a success. After the bankruptcy procedure was completed, the Gdańsk Shipyard (then, a new legal entity) was purchased by the Gdynia Shipyard SA, a shareholder company with the state as the main shareholder. In 2006, Gdynia Shipyard SA sold its share to the State Development Agency. The Polish government decided to privatize and restructure the shipyard also because of pressure from the European Union. In 2008, ISD Polska, a subsidiary of Ukrainian steel producer Donbas, which was already a minority shareholder, became a majority shareholder in the Gdańsk Shipyard. In 2013, about 2100 people worked in the Gdańsk Shipyard, which was less than a third of the workforce of 1990.

In 2013, the Gdańsk Shipyard was once again threatened by bankruptcy and since then, hundreds of workers have been laid off. "Solidarity" together with the shipyard worked out a redundancy payment scheme for those who left the shipyard voluntarily. In July 2018, the Industrial Development 
Agency bought shares in Gdańsk Shipyard (employing only 100 people) from the Ukrainian owner Serhiy Taruta [43]. In December 2018, the Gdańsk Shipyard was officially recognized by the Decree of the Polish President as a "Monument of History" [44]. In the middle of our research project, in the year 2019, the Polish government launched a plan for rescuing the leftovers from Polish shipyards, which were still in operation, including the Gdańsk Shipyard.

\subsubsection{History of the "Solidarity" Labor Union}

The Gdańsk Shipyard was the place where the largest union movement in Eastern Europe was born and later, turned into a mass independence movement. The wave of August 1980 strikes throughout the whole country led to the creation of the Independent Self-Governing Labor Union "Solidarity"—Niezależny Samorządny Związek Zawodowy "Solidarność"— the first independent union organization in communist countries to be recognized by the state. Strike committees throughout the country with the leading Inter-Enterprise Strike Committee of the Lenin's Shipyard in Gdańsk became the founding committees of the Solidarity union. The successful strikers formed the Gdańsk Agreement on 31 August 1980 as an authentic social contract with the government.

It was the beginning of the Solidarity union and beginning of changes in Eastern Europe, which led to the end of the communist system in many countries. On 17 September 1980, over twenty inter-factory founding committees of free labor unions merged at the congress into one national Solidarity Union organization with regional branches. It was officially registered on 10 November 1980 by the Polish Supreme Court. Lech Wałęsa was elected as its first chairman. At its highest, Solidarity had over 10 million members, making it the largest union membership in the world. Its members made 80 percent of all employees of the state-owned companies in Poland. Solidarity had its units in all companies and institutions, except of the Polish army and milicja (the national police forces in several former communist states such as the Soviet Union and the Warsaw Pact countries, among others in Poland).

The new union's supreme powers were vested in a legislative body, the Convention of Delegates. Solidarity's program was formulated at the First Congress of Delegates September-October 1981 ("solidary society and self-governing Poland") and contained the postulates of: defending workers' rights, introducing democratic forms of state election (liquidation of nomenclature, decentralization of economic management, and ensured participation of employees in self-government), guaranteeing the independence of the courts, creating independent territorial and professional self-government, freeing education, culture, science, and mass media from the political and ideological supervision of the communist ruling party, and limiting censorship. The program of Solidarity combined various ideological inspirations: socialist (social justice, self-government, and egalitarianism), Catholic social teaching (social and labor solidarity, rejection of violence in resolving social conflicts), and Polish independence traditions [45].

When we look at Solidarity's program from the perspective of organizational culture, our attention is attracted to the postulates regarding the defense of workers' rights (postulates typical for all labor unions in any economic system) and decentralization of economic management, ensuring the participation of employees in self-government. Crucial characteristics of solidarity organizational culture were decentralization of management (in the socialist system, economic decisions were made by industry headquarters) and the ensuring of the participation of workers in decision-making through a system of workers councils. The activists of Solidarity understood that political emancipation must begin in the workplace, as close as possible to the people and their everyday concerns. The actions of Solidarity led to the passing of a bill by the PRL congress in 1981 that allowed self-governance of the employees in state-owned companies. In the bill, it was stated that in state-owned enterprises, there will exist an elected workers committee and a general assembly of workers with the authority to work as a system of checks and balances over the work of the company and the CEO. These are elements of organizational culture resulting from the socialist heritage that have become part of the Polish postsocialist and post-Solidarity organizational culture. 
Between the years 1981 and 1989, Solidarity organizational culture was not discussed and not developed due to the martial law declared by General Wojciech Jaruzelski on 31 December 1981, to prevent the democratic opposition from gaining popularity and political power in the country. Thousands of people linked to the Solidarity movement, including Lech Wałęsa, were arbitrarily arrested and detained. Throughout the mid-1980s, Solidarity remained as an exclusively underground organization with active local structures built on a culture of trust and solidarity (what seems almost impossible today). Despite the imprisonment of several thousand activists and repressions against protest participants, Solidarity was organizing strikes, demonstrations, and even underground press and book publications. However, in such complex circumstances, Solidarity's actions focused on opposing the authorities and informing the public about arrests and repressions, rather than planning and discussing a new form of social relation (including labor relations) after the awaited victory.

\subsection{Replacing the Culture of Solidarity after the Year 1989}

This part of our research was an attempt to provide a few answers to our first research question: RQ1 How has the process of replacing the culture of Solidarity with neoliberal culture undergone in Polish organizational culture?

In April 1989, the Independent Self-Governing Labor Union "Solidarity" was again recognized by the state as a legitimate organization and Lech Wałesa was elected as its chairman [46]. The victory of candidates supported by "Solidarity" in the first partially free parliamentary elections in June 1989 and in local elections in May 1990, as well as the election of Lech Wałęsa as President of Poland in December 1990, transformed the Solidarity labor union into an organization supporting a new political and economic system, which was not favorable for workers.

While conducting research on the Gdańsk Shipyard and Polish organizational culture, we noticed a significant difference between the official narrative presented by the authorities as well as the broadly defined elite and the narrative of artists and workers. Shock therapy and radical changes in the Polish economy were presented by the authorities, media, and foreign observers as an undoubted success of Poland. However, not all social groups shared this enthusiasm for those changes.

The package of laws changing economic relations in Poland during the transformation to a market economy, called the "Balcerowicz Plan", was passed at a rapid pace, without social or political consultations, except for consultations with International Monetary Fund experts. The package of laws was submitted to the Polish Parliament on 17 December 1989 and was passed on 28 December 1989, with the effective date of 1 January 1990 [47]. The MPs had 11 days to reflect on and discuss the most important and completely new economic solutions, all of which was happening during the holiday season. Law proposals arrived just before Christmas, which in Polish tradition, is an important holiday spent at home, far from Warsaw, the place where the parliament meets. Thus, the changes were not accompanied by a real public debate, not even with the labor unions, even though those decisions concerned the majority of employees in the not yet privatized economy. No alternatives to "shock therapy" were presented at the time, although there were already other proposals for a more gradual exit from the state economy towards the free market [48].

The worsening situation of workers, rising unemployment, and the collapse of companies led to disillusion among the working class. Disappointment was articulated by workers, although outside of the accepted channels of communication (not through labor unions which endorsed the government's decisions), while the majority of the elite, including the elite of Solidarity labor unionists, adopted neoliberal values with hope and trust in the new solutions. This difference caused the split and the final disintegration of Solidarity as a nationwide social movement.

The differences of experiences and narratives between the elites and workers were among the first to be noticed by artists. Art and artists have the ability to uncover hidden areas of the world, including the world of social relations. Contemporary artists often listen to social narratives in order to bring to daylight stories overwhelmed by the dominant narrative and make them, through different aesthetic forms, more comprehensible for the general public. An active presence of contemporary 
art and artists in the Gdańsk Shipyard started in the year 2000 with the historic exhibition Road to Freedom, commemorating the establishment of Solidarity in 1980. The "Artists' Colony" in the Gdańsk Shipyard was established in 2002, in its postindustrial spaces, lasting until the year 2012. Members of the Artists' Colony were participants in the transformation processes and identified the area of the former shipyard as a space of their own experience, memory, and history [49]. They also preserved the narrations of shipyard workers, giving them a voice when their voices were silenced, so that today, we are able to hear them.

The market economy brought about major changes in the labor market, individualization of careers, the emergence of new professions in consulting services, advertising, marketing, and communication, a wide range of liberal professions, as well as jobs in human resources management, and even more so, in capital management with new financial instruments. These phenomena brought about a radical change in loyalty to the employer, and of the employer to the employee, but also in the relations between people in the workplace, and an ever stronger departure from community bonds in favor of mutual competition. This was contrary to the values of the working class, whose social capital is based on ties within a local community and not on competition in the workplace. Work is seen as a source of livelihood for the family and not as a personal development goal [50].

As David Ost pointed out in his book analyzing the defeat of Solidarity: "Solidarity officials at all levels, as well as the intellectuals and professionals who had always been so closely aligned with it, seemed increasingly not just to disregard but also to disown real workers" [2] (p. 5). Solidarity's heritage was not only unpreserved but disregarded and diminished by the former Solidarity activists in order to facilitate the introduction of the neoliberal form of capitalism. It is impossible to determine why it did happen, why people from the working class who were elected for political offices decided to act against their supporters and colleagues.

\subsubsection{Mural "The Shipyard"}

The mural by Iwona Zajac and its creation and perception were the original inspiration for our study visits, although when we were conducting our research, this mural no longer existed in its tangible form. Nevertheless, its moving message persisted, and even became more clear over time.

The wall with the mural painted on fenced the production area of the Gdańsk Shipyard. Along this wall led a walking path to work for many shipyard workers, not only for those who lived in the buildings on Jana z Kolna Street, but also for those who used to come to work by tram and got off at a nearby tram stop. The mural was painted in 2004, during the fall of the shipyard, when many employees were losing their jobs.

Iwona Zając, an artist who was, at that time, a resident of the Artists' Colony in the Gdańsk Shipyard and rented her own studio there, made this mural as her own initiative and paid for it, without using the support of sponsors, because, as she said, she did not want someone else to be able to influence the final shape of her work [51]. It was a monochromatic, blue-black mural painted on the spans of a concrete fence, which consisted of 22 stories of shipyard workers. One of the wall spans showed a naked female figure (accompanied by a dog) against the background with characteristic shipyard cranes, which merged with the figure and formed a kind of broken wings rising from her arms. This woman was later called "Shipyard Nike" and it is a self-portrait of Iwona Zajac, especially since it is the only part mural with Zajac's own words-her credo and her signature: "The Shipyard mural is a recording of my conversations with Shipyard workers. I wanted to tell a story of a man, his fears, needs, dreams; about life, work, plans never fulfilled. I was lucky to be the person the Shipyard workers wanted to share their stories with. This project is my tribute to the people and the place" [52].

On 18 January 2013, the wall with the mural was demolished for the construction of a new road. Between the years 2004 and 2012, Iwona Zając repeatedly repaired painting damage on her mural, and in November 2012, before its final destruction, she started to paint over her mural in black as a farewell to her work. Beforehand, the artist had received an offer to move the mural to the museum space but she rejected it because, as she said in the interview: "she was aware of existing conflicts and was not 
sure how her work could be used for political purposes in the future". In her opinion, acceptance of the offer would be an abuse of trust of the workers who shared their stories with her. Currently, she runs the website http://www.stoczniaweterze.com, where her mural can be seen. This Internet site also provides the possibility to listen to the original recordings of interviews with shipyard workers, which she had recorded years ago. Some of the interviewed workers still live on Jana z Kolna Street where the original painting was made [53]. On the mural, workers' statements were anonymous, while for the purpose of the website, most of them decided to disclose their names, although some remained anonymous.

\subsubsection{Narratives of Workers}

This mural was a story of shipyard workers told by themselves. They talked mainly about their work, their concerns about losing their jobs, but also about their dreams and families. Zajac gave voice to those who are usually silent and giving a voice to subordinate groups is the main postulate of postcolonial theories. It is moving to realize that some of these shipyard workers started working for the Gdańsk Shipyard at the age of 14 (as students at the factory school) and worked there all their lives (Wall 6 and Wall 18). They wanted to work until retirement, because as they said:

"When they were closing down some of the workshops, I didn't feel good because without a job-where, or what should I do? Steal or what? It was unpleasant. If you're young it's not a problem, if you've got skills you will always find something, but when you're old you have to stick to one place (Wall 3, Władysław Skoworodko)" [52].

They mainly talked about work, its importance, and their difficulties with watching the fall of the shipyard:

So much work has been put into this place, so many people used to work here and now it's all disappearing. I can't describe these feelings (Wall 4, Stanisław Sukiennik). [52]

It's sad because one worked here for so long and saw this workplace thrive, and suddenly they made a desert out of it. It's not worth talking about it. It won't change a thing (Wall 5, Tadeusz Rogalski). [52]

A man was eager to work, he would go to the shipyard with pleasure. Now it's sad to even look at the shipyard. When they were cutting the machines to sell them for scrap my heart was breaking (Wall 8, Stanisław Ostrowski). [52]

Selling of the shipyard is painful for the workers. A wealth elaborated by our grandparents was passed on so easily, somebody got rid of the land, machines, buildings. It hurts (Wall 13, Ryszard Kuffel). [52]

They talked about long-lasting friendships, about funerals they attended, about a sense of belonging, and the close relations:

I came here one day to see the sea and I ended up in the shipyard. Before I came here, I hadn't even imagined how it all might look. Now the shipyard is like my family. I went through almost all of its history, I took part in the demonstrations. I didn't play any important part in the strikes. When the strike was to begin, everyone took part in it. People were really afraid back then. There was no place for plans or dreams. I am strongly connected to this place. We don't get paid for months and yet people come to work (Wall 16). [52]

The shipyard was, to some extent, a great family and, at the same time, a patron. A lot of people lost part of themselves with its closure. 
In those days the shipyard cared for each worker, gave him accommodation. People were directed to flats or to workers hotels. The shipyard employed everyone. Unskilled people, former prisoners. Lads were from the villages from the middle of Poland, from voivodeship of radomskie, kieleckie, lubelskie. They were coming with one suitcase or sometimes with no suitcase at all. After a few years they had flats, got houses, found their wives here. You can say they found a second home here. People spent most of their time in the shipyard (Wall 20, Henryk Donskoi). [52]

(... ) at this moment we usually meet on sad occasions like funerals. Everybody shows up there as if on a last duty, on a last meeting. And it's very elevating. These celebrations always strengthen our respect for ourselves, for life, for passing time (Wall 22, Czesław Szulkt). [52]

These stories are very different from the narration of the manual workers (of an engineer ex-shipyard worker, an expert on city politics, and the employees of the European Solidarity Centre), who stressed the fact that the fall of the shipyard was an economic problem at its core, not a social one. This was supported by the argument that all of the workers that were made redundant received severance pay and all of those interested received often more financially attractive offers in Poland or abroad. Those same non-physical workers spoke of the political problem, in which the Solidarity symbol was disappearing. However, the Shipyard workers viewed it as a social problem that touched them personally with serious implications for their families and for the social bonds they created.

\subsection{Present Situation on the Site of Former Shipyard}

This part of our research deals with a research problem stipulated in the second research question: RQ2 How does the new hybrid form of this culture look in the widely understood public domain around the Gdańsk Shipyard?

The researchers stayed in two rented flats within the area of the former shipyard: in 2018, it was a modern apartment in a newly built, high apartment building, one of the Young City developments. In 2019, it was a flat in a rundown, red-brick building, which was initially built for workers and located on Jana z Kolna Street. Between them, there was a big square, Solidarity Square, with the iconic older monument, the Monument to Fallen Shipyard Workers, the historical building of the Occupational Health and Safety Hall, and the newly constructed European Solidarity Centre (ESC).

These two apartment buildings, located only a few hundred meters apart, gave the impression that they existed in two completely different realities. The newly built apartment building was overwhelming with the excess of luxury-carpets in the corridors, balcony terraces, which were made out of glass without visible structural elements and gave the impression of floating in the air over the historic panorama of the city—a flat with very modern, expensive equipment (Figure 1).

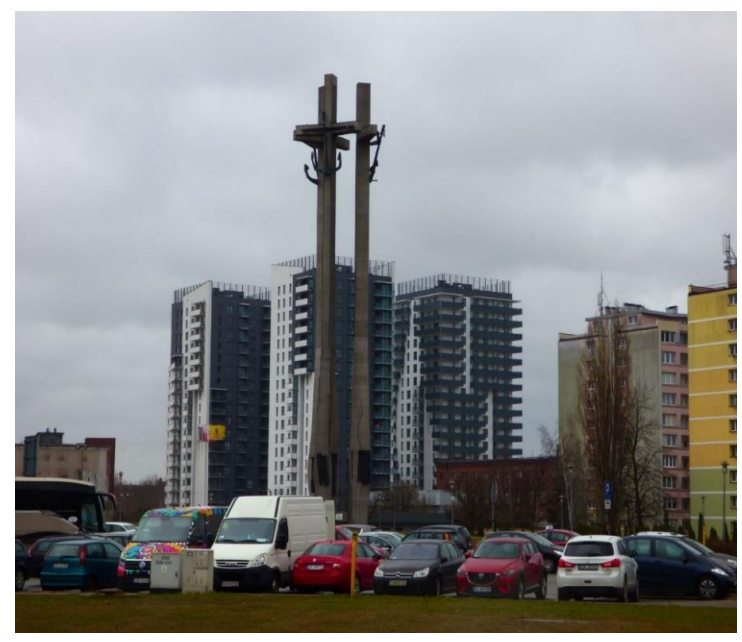

Figure 1. Newly constructed high apartment buildings on Wałowa Street. 
The impression of luxury was compounded by the contrast with the local health center, located just behind the fence, which separated a group of several apartment buildings (a guarded mini estate) from other buildings. It is one of the main signs of the neoliberal urban regime, in which fencing off space within the city for the richer inhabitants is a standard. The Young City tries to separate itself from the old shipyard, but this separation is never complete. The health center was located in an old, damaged red-brick building with a pharmacy on the ground floor. While shopping at the pharmacy, one of the researchers overheard conversations of other people standing in the queue, mainly older, modestly dressed women. They were wives or widows of shipyard workers, and the main topic of conversation was poor health and high, not affordable for them, prices of medicines. It is difficult to say whether the owners of the expensive, modern flats from the neighboring buildings use a local health center, but, as the pharmacy's offer (expensive cosmetics and supplements) suggests, they visit the nearby pharmacy and meet with poor, ill shipbuilders who are in short supply for medicines. They can enter the space of shipyard workers and their families, while their space-the fenced Young City-remains closed in its present form to the workers. This is typical of neoliberal urban policy, in which the pursuit of profit obscures the essence of urban public space. As Iwona Sagan notes, "in the city landscape they are (fenced settlements) a manifestation of social divisions, a symbol of polarization and conflicts of the local community" [54] (p. 17).

During the next study visit in March 2019, the researchers stayed on Jana z Kolna Street. It was a destroyed, workers' building, which used to be adjacent to a long wall fencing the shipyard that no longer exists. Between the years 2004 and 2012, there used to be a mural painted on this wall by Iwona Zajac. The mural was entitled "Shipyard" and now, on the wall of this apartment building, there is information about it and a QR code redirecting to its webpage http://www.stoczniaweterze.com (Figure 2). This Internet site has a Polish and an English version and it presents pictures and information about the mural [52].

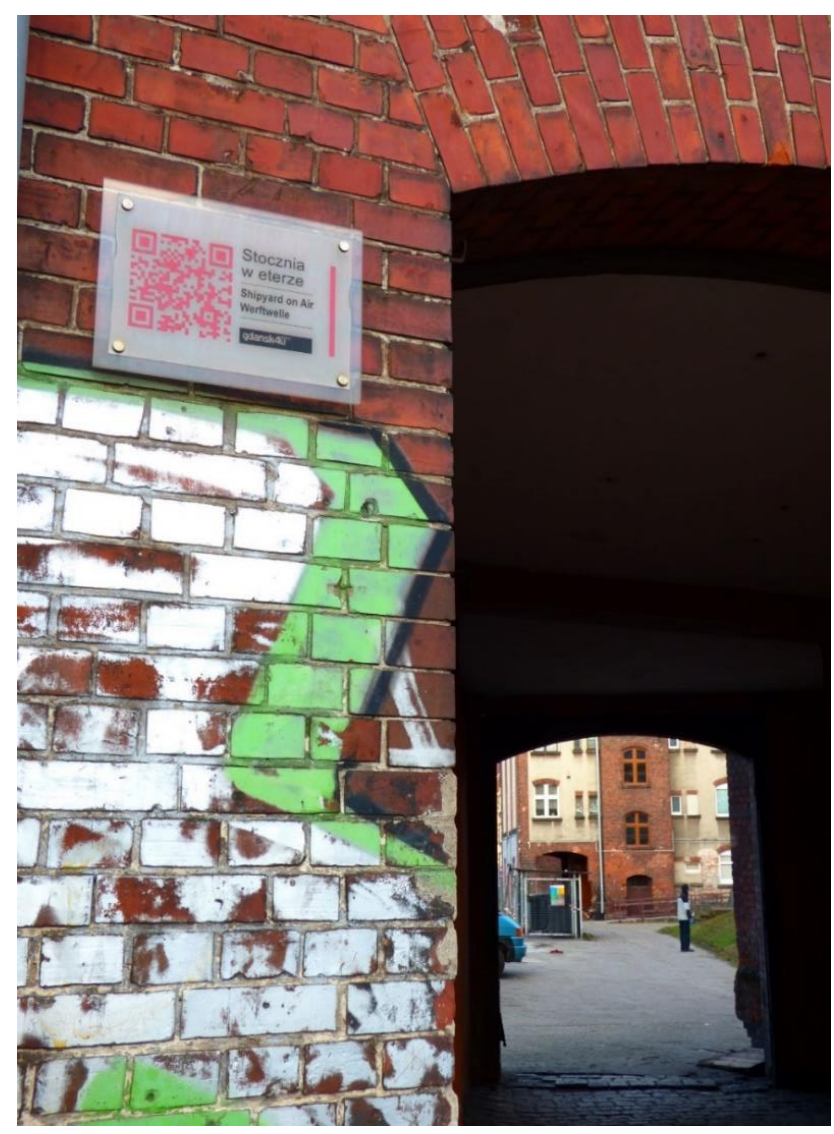

Figure 2. QR code redirecting to mural's page. 
The building we stayed in is one of the several old, red-brick apartment blocks standing next to each other that create a small community (Figure 3). As an expert in urban policy in Gdańsk, who used to conduct in this area field studies with students, has explained to us, this area was the so-called "Bermuda triangle"- a place considered dangerous, where many social problems were observed. The feeling of abandonment, neglect, and lack of hope (as well as the concern of the residents of Gdańsk, which we interviewed in the rented apartment) was saddening. We wanted to interview people living in this building, earlier asking the owners of the apartment to help us make contacts, but their efforts proved fruitless and we were told the neighbors did not want to talk to us. We stayed there only for a few days, too short to build a mutual trust.

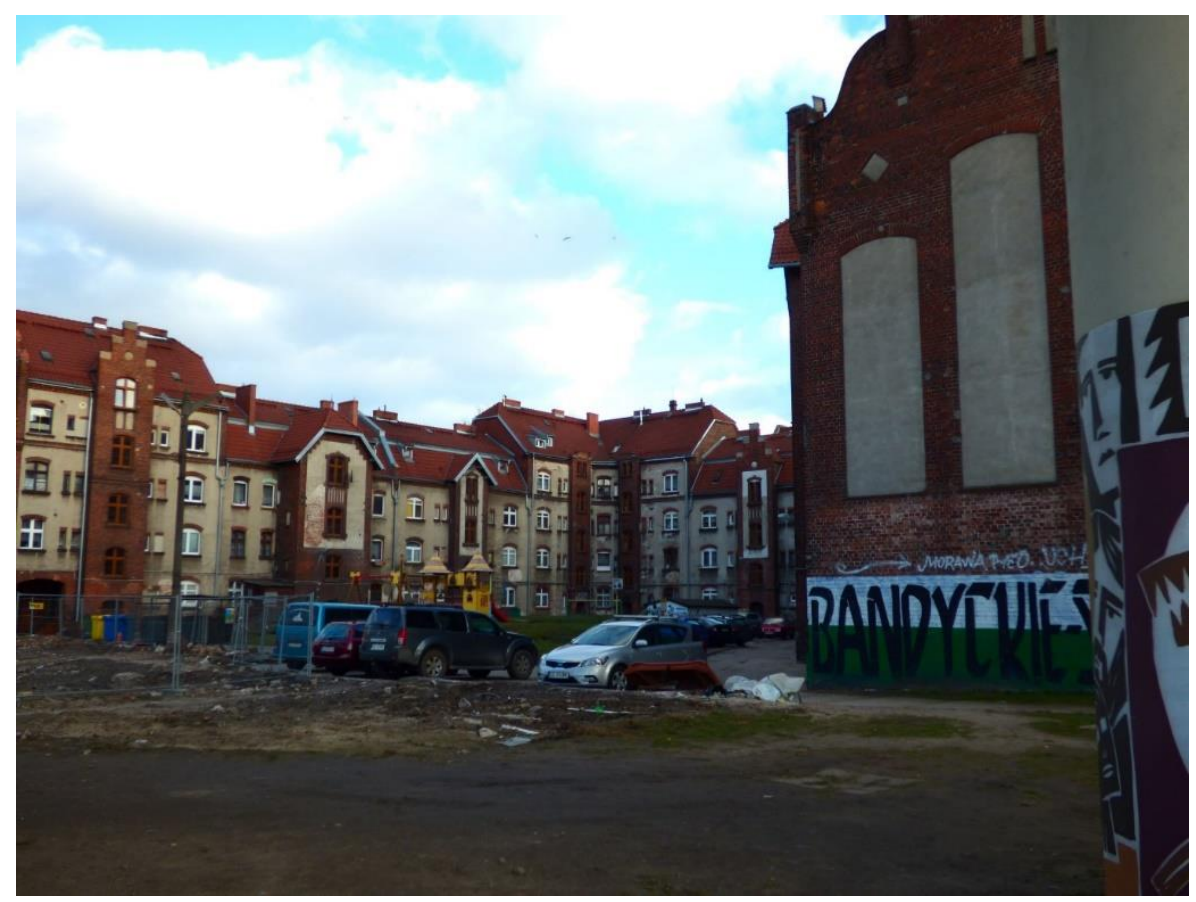

Figure 3. The courtyard of the apartment building on Jana z Kolna Street.

In our view as outsiders, this mini neighborhood, one of many similar places, was inhabited by people whose world in a sense has ended. Many of them worked their entire career in the shipyard, which organized their whole lives-not only work, but also provided kindergartens for children, schools, health care, cultural activity and leisure, canteens, shops, and social security for employees and their families and for retirees. The Gdańsk Shipyard was in the times of the People's Republic of Poland an almost self-sufficient organism, "a city in a city". It was not only a place of work, but also a place where leisure time was spent. It had its own holiday centers, kindergartens and nurseries, a hospital, a community center with a cinema and library, and a sports hall. The shipyard workers and their families could play in the shipyard orchestra and participate in the activities of a dance group or sports section-from skating to boxing.

The collapse of the shipyard was not just a loss of jobs, it was a destruction of an entire way of life. We do not try to judge whether it was good or bad-we just notice that it was so, that the shipyard was also a certain community, a kind of "family" for many of them.

\subsubsection{Solidarity Square}

Solidarity Square is centrally located and visited by many people. This part is the most developed and has two functions-touristic and symbolic, as a place for celebrating Solidarity-related celebrations. Since 1980, the Monument to Fallen Shipyard Workers commemorating the victims of December 1970 (Figure 4), designed by Bogdan Pietruszka, Robert Pepliński, Elżbieta Szczodrowska-Peplińska, 
and Wiesław Szyślak, has been standing there. These are three very high crosses (42 m) with reliefs picturing the lives of shipyard workers. An anchor is hung on each cross. The crosses, built on a triangular plan, have irregular, cracked shapes. The monument was designed and made in the Gdańsk Shipyard by the workers themselves.

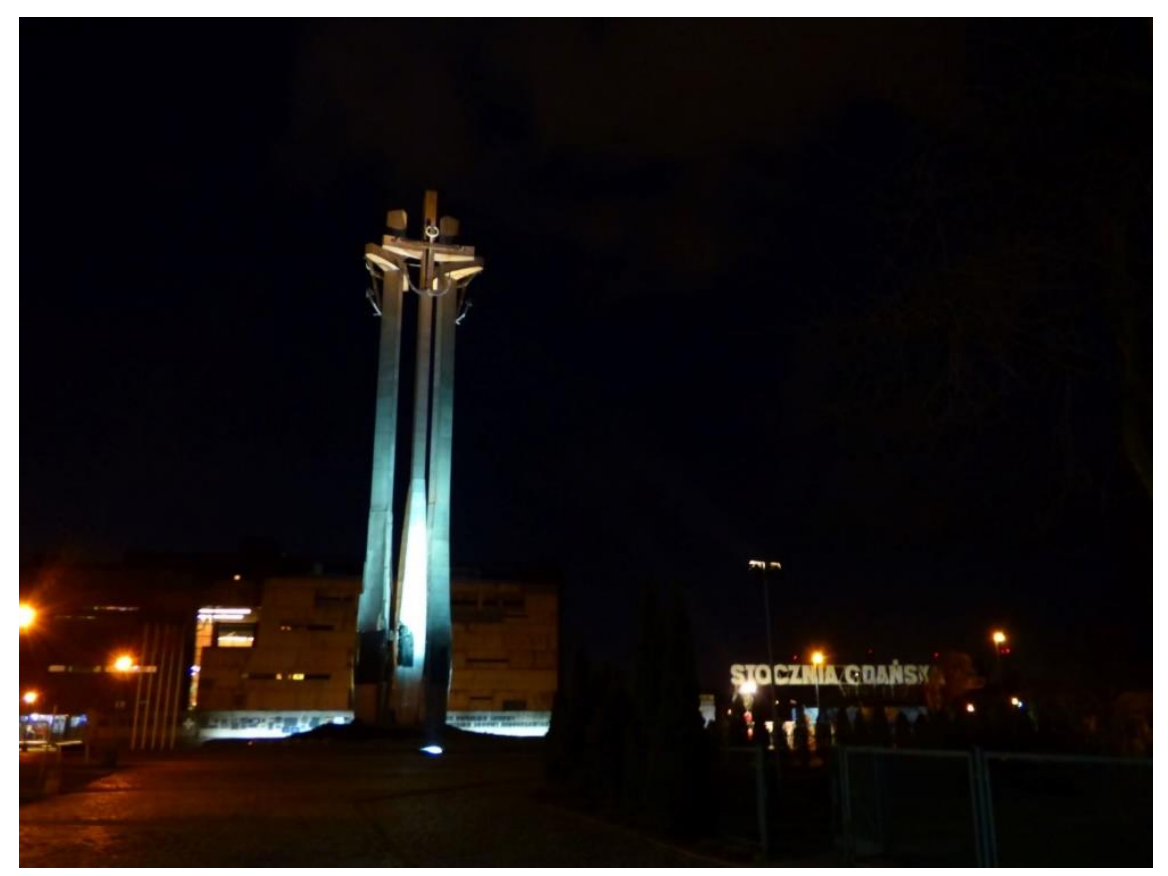

Figure 4. Monument to Fallen Shipyard Workers.

Right next to the monument, there is the historical Gate No. 2, which was formerly the main gate of the Gdańsk Shipyard. In the vicinity of this gate, 2 people were killed and 11 wounded by bullets on 16 December 1970, during the pacification of the strike of shipyard workers. Prior to the creation of the Monument to Fallen Shipyard Workers, the gate itself was the first place of remembrance for the victims of December 1970. People placed near the gate flowers and candles for each anniversary of the protest.

During the strikes in August 1980, it became the main place of contact for the striking workers and their families and supporters, as well as a symbolic grandstand from which current announcements were made. It was also the place where the strike leader Lech Wałesa announced the signing of the Gdańsk Agreements and the end of the protest. Currently, it has a museum function.

Close to Gate No. 2, there is the building of the European Solidarity Centre (ESC), opened in 2014 (Figure 5). The aim of the center is to popularize the heritage of "Solidarity", as well as the universal values encoded in this name and materialized in the social movement that embraced the whole of Poland and has been admired and supported by societies in many countries of the world. It is a large modern building with various functions-it is a museum commemorating the revolution of Solidarity and the fall of communism in Europe, but also an educational center, a research and development center, an archive, a library, and a media center. However, the activities of the ESC are contested by most of the former shipyard workers-the workers and the contemporary Labor Union "Solidarity", who think that there is no room for them there. They still meet in the former Health and Safety Hall, where the August 1980 Agreements were signed, despite the fact that "Solidarity" was one of the founders of the ESC. 


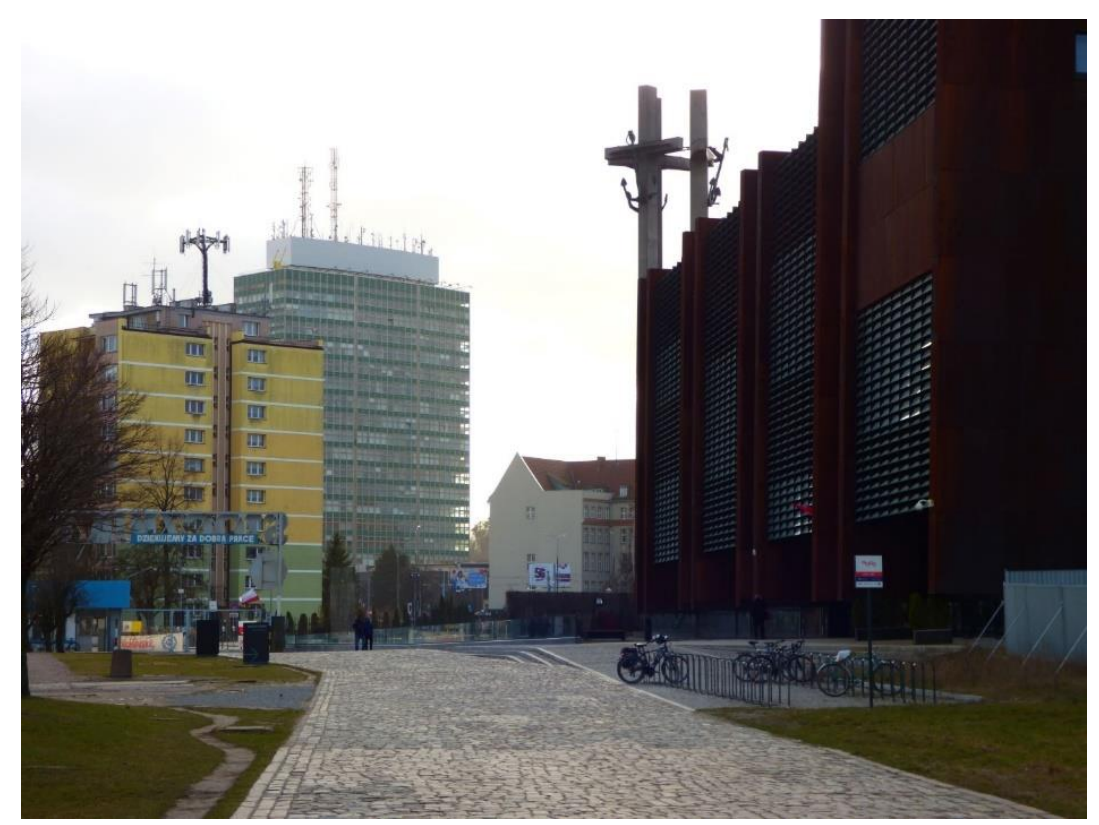

Figure 5. From the left: Gate No 2, the Monument to Fallen Shipyard Workers, and the European Solidarity Centre.

In the Health and Safety Hall, there is an exhibition, alternative to the one exhibited at the European Solidarity Centre, showing the history of "Solidarity" (Figure 6). The former Occupational Health and Safety Hall is located just a few dozen meters away from the new ESC building and until recently, it was financed by a special state subsidy provided through the ESC. Since 1 January 2020, it has been financed by a government subsidy provided directly to the Solidarity Promotion Foundation, which manages that building.

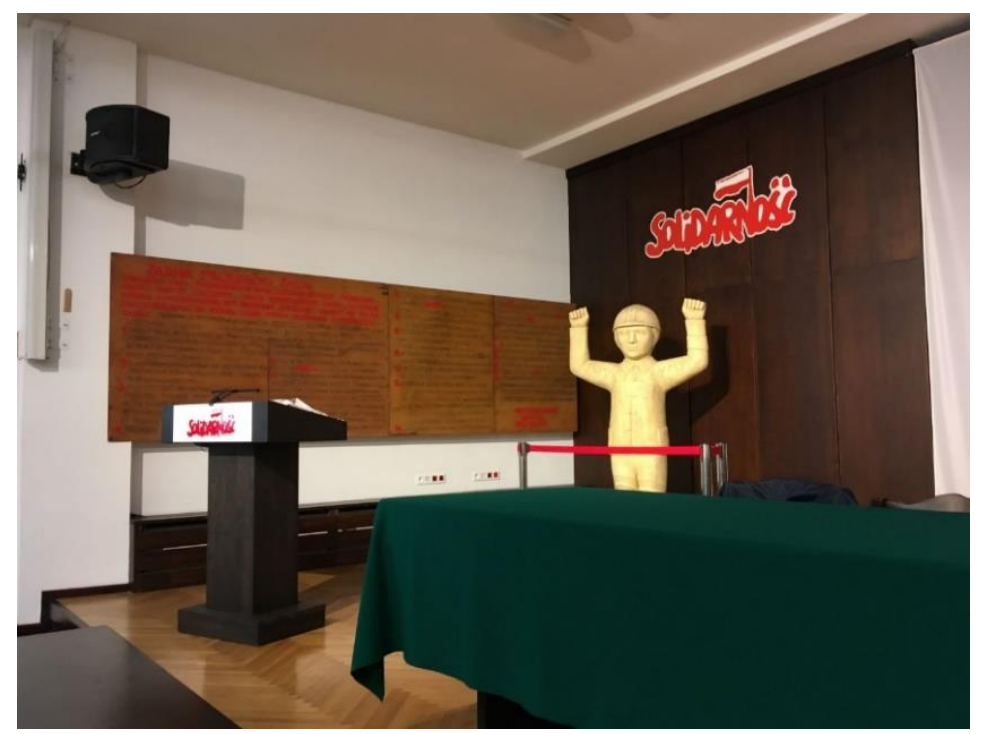

Figure 6. Replica of the boards with 21 postulates in the Health and Safety Hall.

Since 2019, the "Solidarity" Labor Union, which, while retaining its symbolic name, was gradually becoming more and more politicized during the transformation period, has been trying to collect the original August 21 postulates from the European Solidarity Centre with a view of presenting them at the exhibition in the Health and Safety Hall [55]. The boards, on which the striking shipyard workers wrote down 21 postulates in 1980, were recognized by the International Advisory Committee 
of the UNESCO Memory of the World Programme as one of the most important documents of the 20th century, testifying to the events which had a breakthrough impact on the political and economic changes in the countries of the socialist bloc. On 16 October 2003, the plaques with 21 postulates were inscribed on the UNESCO World Heritage List.

The "Solidarity" Labor Union believes that these boards are the property of the labor union, or more broadly, of the workers, and not of the European Solidarity Centre, which only received them in deposit (Figure 7). In the opinion of Solidarity activists, the European Solidarity Centre is more concerned with meeting the expectations of the West (Western tourists and pro-European elite) than with the actual preservation and maintenance of Solidarity heritage. This dispute over the 21 postulates' boards is a symbolic expression of a deep collision of two organizational ideas/cultures: community and neoliberal.

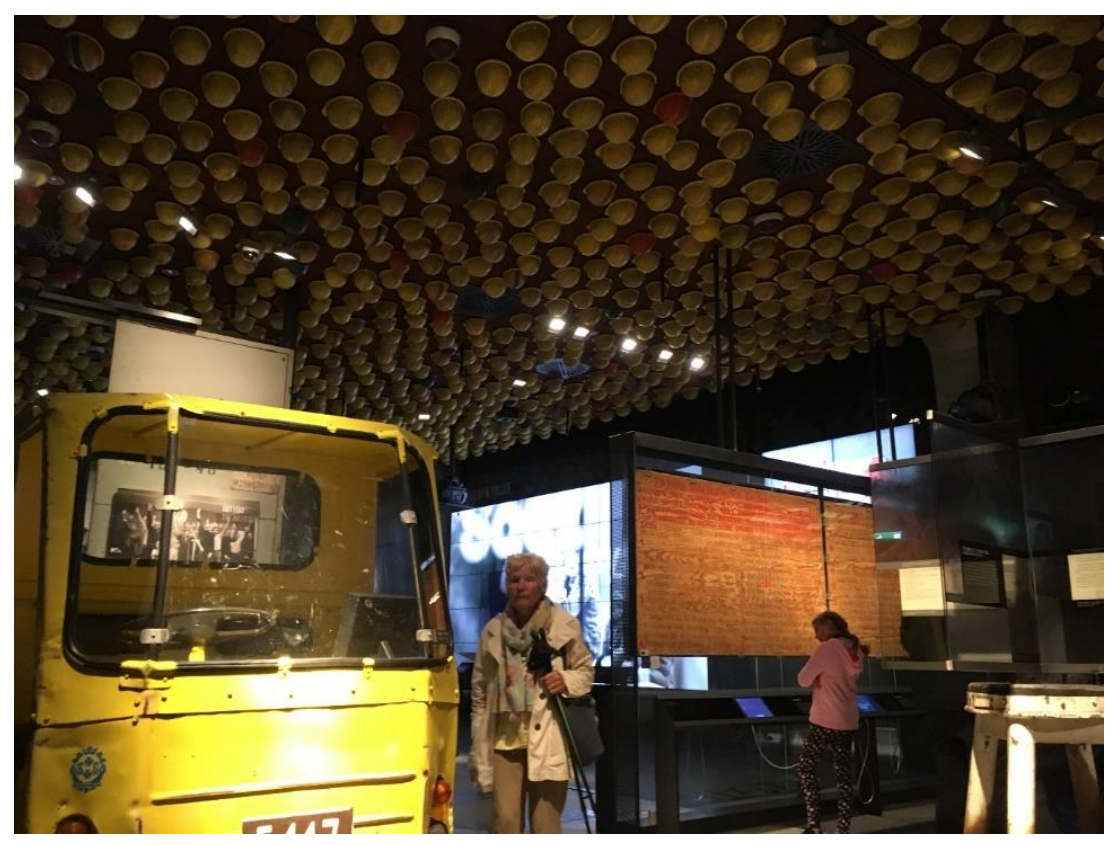

Figure 7. Original boards with 21 postulates in the European Solidarity Centre.

In a sense, the dispute around the European Solidarity Centre reflects the main dispute also taking place in the Labor Union "Solidarity" about the dominant narrative: will it be a normalizing, Western, European narrative or a more communitarian one, referring to the heritage of "Solidarity" as a labor union? As Joseph Stiglitz pointed out:

(... ) the success of market economy cannot be understood in terms of narrow economic incentives: norms, social institutions, social capital and trust play critical roles. ( ... ) One of the most difficult parts of transformation, such a transition from socialism to a market economy, is the transformation of the old "implicit social contract" to a new one. If "reformers" simply destroy the old norms and constrains in order to "clean the slate" without allowing for the time-consuming process of reconstructing new norms, then the new legislated institutions may well not take hold [30] (p. 173).

\subsubsection{Młode Miasto (Young City)}

In 1999, the Gdańsk Shipyard started to move its very limited production activities to Ostrów Island. Currently, this area is occupied by two small companies: the Gdańsk Ship Repair Yard and the Gdańsk Shipyard. It is an isolated area, separated by a channel, with restricted access (Figures 8 and 9). 


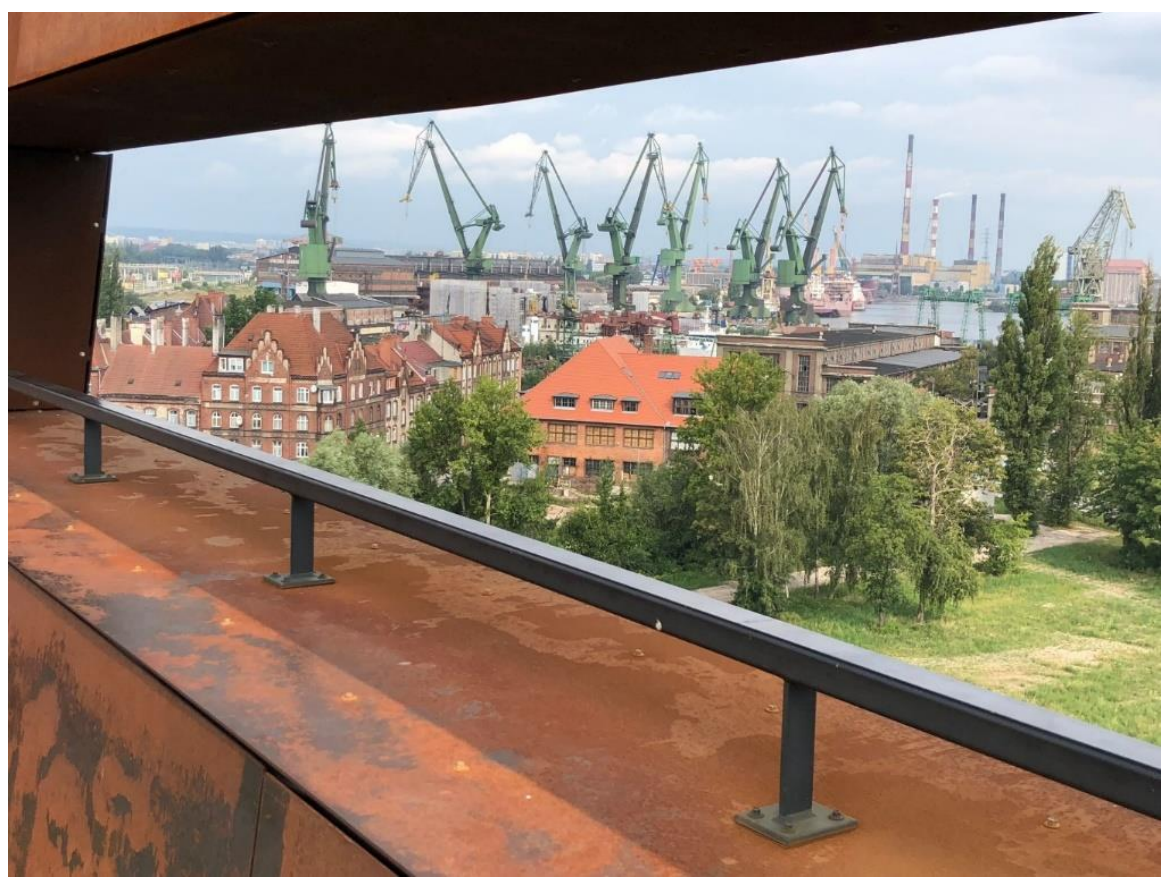

Figure 8. View from the roof of the European Solidarity Centre over the channel.

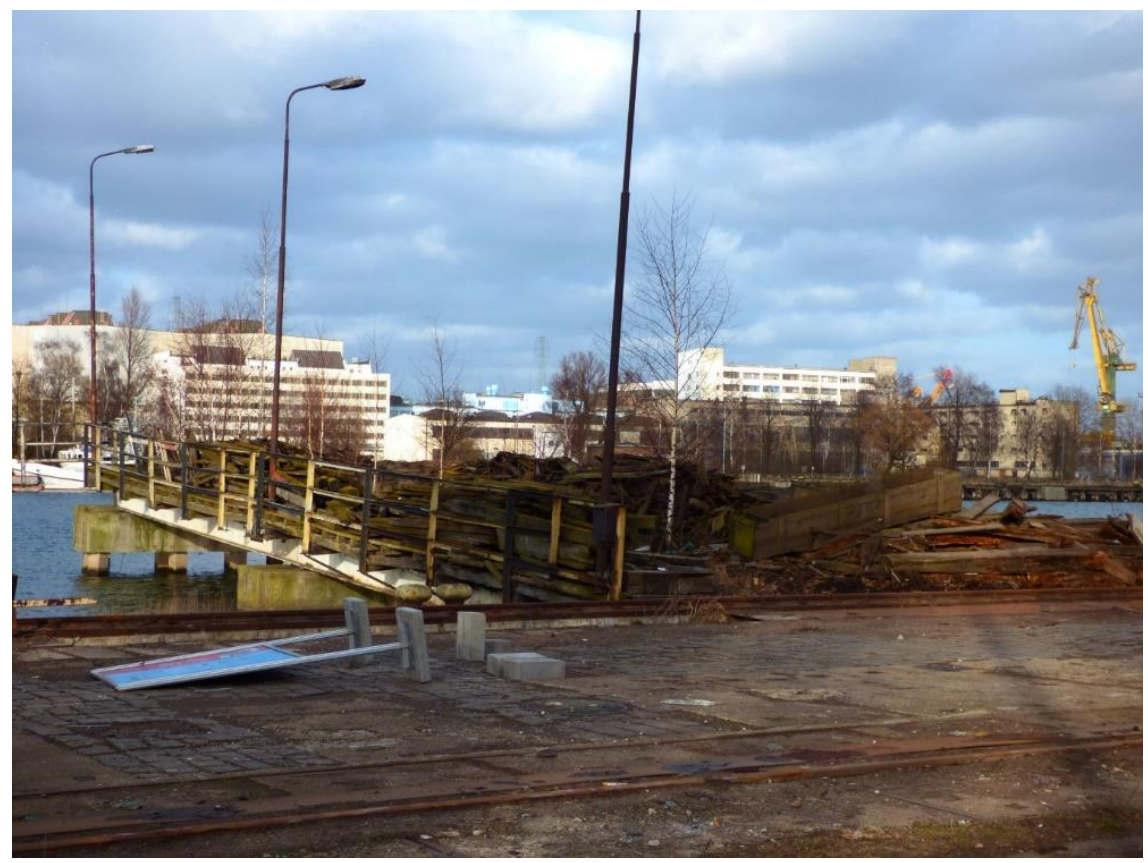

Figure 9. Ostrów Island over the canal.

As a result of ownership changes and functional transformations, the southern part of the area of the former Gdańsk Shipyard S.A. was excluded from production activities, and this area, called the Young City, was intended for urban development purposes. The yard's area has been transformed from industrial into a built-up area and as such, is the subject of analysis in the study on changes in organizational culture. It is an example of a change in the company's resource management concept. It is a physical manifestation of a profound change in the value of postsocialist organizational culture, which in the socialist period was based on industrial development (if not always on technological development, then, always on territorial expansion-the development of the company was understood as an increase in its size). It is also a change in a company's development and assets management. 
At the same time, the neoliberal urban regime is a change in the way the city is managed, leading to significant changes of public space, both physical and symbolical. Cities in the socialist system were not an autonomous subject of urban policy. They were planned at the national level with implementation at the local level, and were heavily subordinated to the interests of large industrial plants. This included the lack of restrictions in territorial expansion (extensive use of space), as well as specific rules in meeting the needs of their employees, leading to the state when the workplace was the main environment for building social relations [56] (p. 153). The most clear manifestations of neoliberal urbanism include the spilling of cities in the form of growing suburbs, the fragmentation of city space, and its social polarization materializing, among others, in the form of fenced settlements. These processes cause an inevitable increase in car traffic and changes in transport accessibility, but also erosion of public space. The city planning process is under increasing pressure from market values and "entrepreneurial" attitudes and gives rise to protests from permanent, more community-oriented residents [57]. This process can also be observed in the post-shipyard area, in the Young City in Gdańsk

It is a very attractive investment area, located in the immediate vicinity of the historical city center. It is developing dynamically_new roads are being built and small businesses are developing in former shipyard buildings, mainly clubs, bars, or restaurants (Figures 10 and 11).

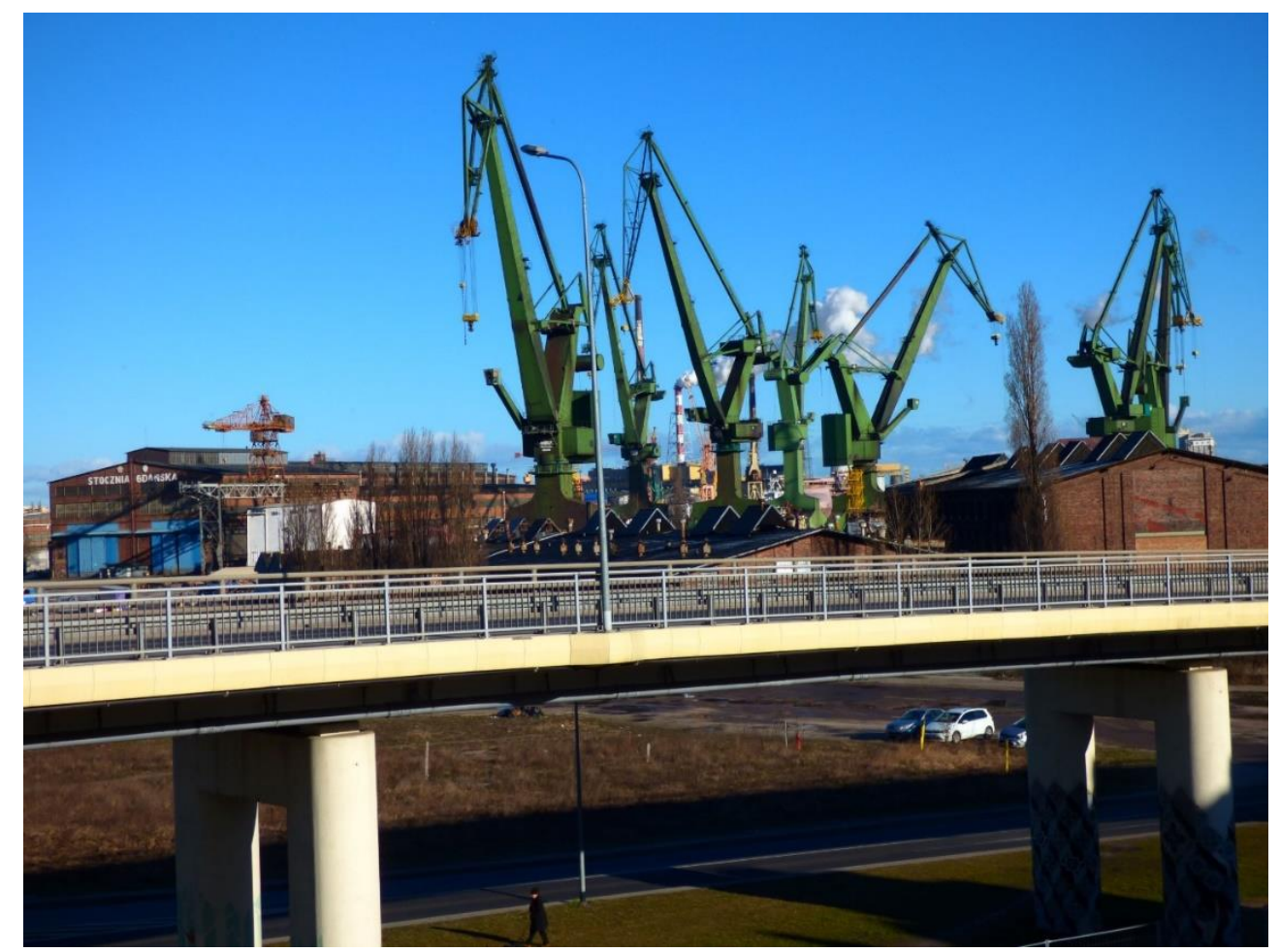

Figure 10. Newly constructed road in the former shipyard.

New residential buildings were constructed, making a striking contrast with rest of the area. They are very high apartment buildings, providing a captivating view for their inhabitants, but simultaneously, blocking out the view of the historical shipyard panorama for the rest of the people. Their presence ignites protests of the inhabitants of Gdańsk and visitors. In 2017, the Pomeranian Voivodship Conservator of Monuments started the procedure of entry into the register of monuments of the Pomeranian Voivodship a part of the former Gdańsk Shipyard, which includes the historic area of the Schichau Shipyard. The procedure was started only a few days after one of the investors in this area had announced the intention to build a 97-m high office building (the second tallest building in Gdańsk) at Jana z Kolna street [58]. The decision regarding the entry to register was made on 7 January 2020, after numerous public consultations, mediations with investors, and proceedings 
before an administrative court at the request of the investors. The decision comes with a multipage justification based mainly on conservation expertise, but it also includes a reference to the historical heritage of the Solidarity movement and stipulates various public initiatives aimed at saving the heritage of the Gdańsk Shipyard. Its summary states: "It is in the well-understood public interest to preserve the historical and cultural heritage of the region as a common good for future generations, as it is guaranteed in the Constitution of the Republic of Poland of 2 April 1997" [59] (p. 16). This decision has also limited the height of newly built facilities. Disputes over the development of the area of the former Gdańsk Shipyard, mirrored also in the conservator's decision, show the tensions between a neoliberal vision of urban space with its main idea of maximizing profit and a post-Solidarity attempt to protect a common heritage.

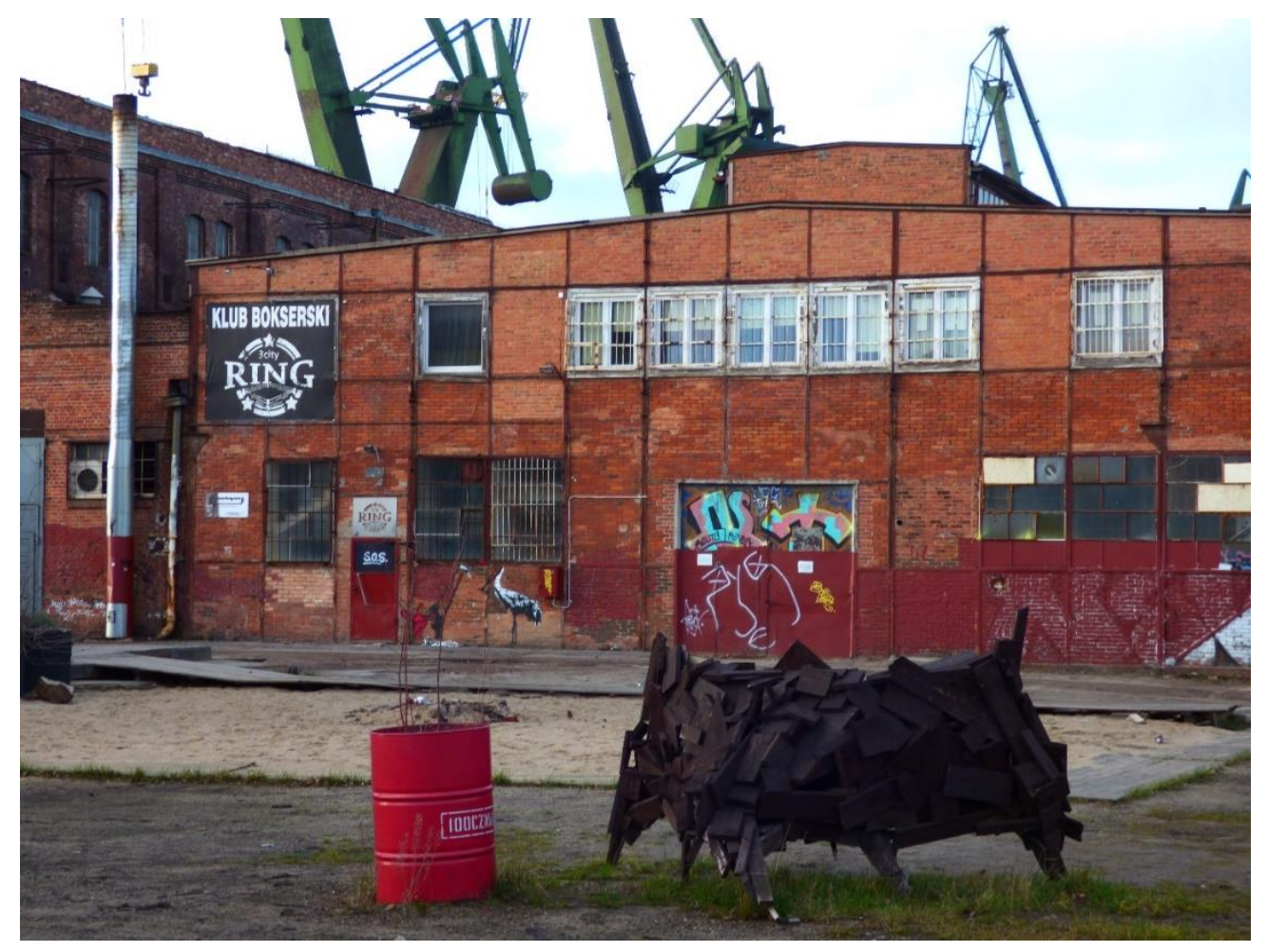

Figure 11. Boxing club in the former shipyard's building.

\section{Conclusions}

Our field research is only an introduction to a deeper analysis of Polish organizational culture and the way Solidarity culture has been replaced by neoliberal organizational culture. Based on the results of our research, it can be concluded without any doubt that this process has not yet been completed and was not collision-free. In the description of our research methods, we have provided a definition of Denzin's and Lincoln's qualitative research, seen as "an activity that places the observer in the world and makes the world visible". Our research has revealed certain areas of social reality that have remained hidden, especially the tension between a solidarity-based organizational culture and neoliberal culture. These cultures were contrasted with each other, with the dominant narrative presenting solidarity organizational culture as opposed to the free market economy. However, the local community associated with the Gdańsk Shipyard, which de facto incurred the costs of market transformation, was opposed not to the free market, but to the radical program of privatization, imposed on them without social dialogue and without giving a voice to the people for whom the culture of solidarity was a real alternative to real socialism. The technocratic discourse on production efficiency at Gdańsk Shipyard (and other former state-owned enterprises) and issues of management efficiency have obscured the social dimension of organization and management. As G. Prawelska-Skrzypek 
and M. Lenartowicz point out, the organization and management studies have been dominated by the economic approach, which puts efficiency at the center, rarely posing the question-efficiency for whom? [60]. The economic way of thinking prefers private property over the common good and financial benefits over social benefits, however, the main task of public authorities and thus, of people managing the public sphere must be the common good.

In response to RQ1 (How has the process of replacing the culture of Solidarity with neoliberal culture undergone in Polish organizational culture?), it can be said that it was a process that aroused social resistance, which was suppressed by the official narration. This resistance was articulated by workers, although outside the accepted channels of communication (not through trade unions), while the majority of the elite, including the elite of the Solidarity trade unionists, adopted neoliberal values.

The market economy brought about major changes on the labor market, individualization of careers, the emergence of new professions in consulting services, advertising, marketing, and communication, a wide range of liberal professions, as well as jobs in human resources management, and even more so, in capital management with new financial instruments. These phenomena brought about a radical change in loyalty to the employer and the employer to the employee, but also in the relations between people in the workplace and an ever stronger departure from community bonds in favor of mutual competition. This was contrary to the values of the working class, whose social capital is based on community ties and not on competition at the workplace.

The worsening situation of workers, rising unemployment, and the collapse of companies have led to a return to community values of solidarity, also within the Solidarity trade union itself. In Poland, in the process of transition to a market economy, too little emphasis has been placed on social and economic cohesion, focusing primarily on one-dimensional productivity at all costs and on efforts to catch up with the West in terms of consumption. This has resulted in a deep split in society.

The answer to RQ2 (What does the new, hybrid form of this culture look like in the broadly understood public space around the Gdańsk Shipyard?) is more ephemeral. This new form of culture is constantly changing. Referring to the previously discussed Bhabha's concept of hybridity and the mimicry of cultures, who believed that hybridity results from various forms of colonization leading to the collision of cultures and at the same time, to the exchange between cultures, it should be considered that we are dealing with a combination of solidarity and neoliberal culture. It is not, however, a coherent, completely interconnected form.

The narrative of the "return to Europe" or "return to the West" with globalization and the accompanying technologies (both industrial and communication), techniques (measuring, managing and producing), and liberal concepts of the person, has also left its mark on people who postulate a "return to Solidarity". Not only did 30 years of practicing the neoliberal economy leave its mark, but also, a flawless political game in a young, maturing democracy. It is appropriate to agree with Bhabha and look for solutions adequate to the current state of culture, perception of the values of social cohesion and solidarity, social bonds, greater economic equality, or the concept of a socially immersed person.

Our research also points to the need to redefine the current understanding of organizational culture by strengthening the understanding of its local level and the ways in which cultural analysis is carried out in the sciences of organization and management. A way to deepen our understanding, as postcolonial researchers postulate, is to cast the voice of the local community and make sure that future empirical work really takes into account the voice of people from subordinate groups and is not just another voice of the privileged group.

Author Contributions: Conceptualization: G.P.-S. and A.M.; methodology: G.P.-S.; investigation, G.P.-S. and A.M.; data curation: G.P.-S. and A.M.; writing-original draft preparation: A.M.; writing-review and editing, G.P.-S. Photos 1-5 and 9-11: G.P.-S., photos 6-8: A.M. All authors have read and agreed to the published version of the manuscript.

Funding: This research received no external funding.

Conflicts of Interest: The authors declare no conflict of interest. 


\section{References}

1. Dunn, E. Prywatyzując Polskę: O Bobofrutach, Wielkim Biznesie i Restrukturyzacji Pracy, 2nd ed.; Wydawnictwo Krytyki Politycznej: Warsaw, Poland, 2017.

2. Ost, D. Defeat of Solidarity: Anger and Politics in Postcommunist Europe; Cornell University Press: Ithaca, NY, USA, 2005.

3. Bogacz-Wojtanowska, E.; Góral, A.; Bugdol, M. The Role of Trust in Sustainable Heritage Management Networks. Case Study of Selected Cultural Routes in Poland. Sustainability 2019, 11, 2844. [CrossRef]

4. Hofstede, G.; Hofstede, G.J.; Minkov, M. Cultures and Organizations. Software of the Mind. Intercultural Cooperation and Its Importance for Survival; E-book; The McGraw-Hill Companies: New York, NY, USA, 2010.

5. Bhabha, H. The Location of Culture; Routledge: New York, NY, USA, 1994.

6. Bourdieu, P. Reguty Sztuki. Geneza i Struktura Pola Literackiego; Universitas: Cracow, Poland, 2001.

7. Kates, R.; Parris, T.; Leiserowitz, A. What is Sustainable Development? Goals, Indicators, Values, and Practice, Environment. Sci. Policy Sustain. Dev. 2005, 47, 8-21. [CrossRef]

8. Report of the World Commission on Environment and Development: Our Common Future 1987. Available online: http://www.un-documents.net/our-common-future.pdf (accessed on 28 April 2020).

9. Gusfield, J. Culture. Context 2006, 5, 43-44. [CrossRef]

10. Benedict, R. Configurations of Culture in North America. Am. Anthropol. 1932, 34, 1-27. [CrossRef]

11. Geertz, C. The Interpretation of Cultures: Selected Essays, 3rd ed.; Basic Books: New York, NY, USA, 2017.

12. Said, E. Orientalism: Western Conceptions of the Orient; Penguin: London, UK, 1978.

13. Jack, G.; Westwood, R. International and Cross-Cultural Management Studies: A Postcolonial Reading; Palgrave Macmillan: Basingstoke, UK, 2009.

14. Jack, G.; Westwood, R.; Srinivas, D.; Sardar, Z. Deepening, broadening and re-asserting a postcolonial interrogative space in organization studies. Organization 2011, 18, 275-302. [CrossRef]

15. Chari, S.; Verdery, K. Thinking between the Posts: Postcolonialism, Postsocialism, and Ethnography after the Cold War. Comp. Stud. Soc. Hist. 2009, 51, 6-34. [CrossRef]

16. Şandru, C. Worlds Apart? A Postcolonial Reading of Post-1945 East-Central European Culture; Cambridge Scholars Publishing: Newcastle Upon Tyne, UK, 2012.

17. Todorova, M. Imagining the Balkans; Oxford University Press: Oxford, UK, 1997.

18. Goldsworthy, V. Inventing Ruritania: The Imperialism of the Imagination; Yale University Press: New Haven, CT, USA, 1998.

19. Kiossev, A. The Self-Colonizing Metaphor. Available online: http://monumenttotransformation.org/atlas-oftransformation/html/s/self-colonization/the-self-colonizing-metaphor-alexander-kiossev.html (accessed on 15 June 2020).

20. Śliwa, M. Understanding social change through post-colonial theory: Reflections on linguistic imperialism and language spread in Poland. Crit. Perspect. Int. Bus. 2008, 4, 228-241. [CrossRef]

21. Thompson, E. Trubadurzy Imperium. Literatura Rosyjska i Kolonializm; Universitas: Cracow, Poland, 2000.

22. Janion, M. Niesamowita Stowiańszczyzna: Fantazmaty literatury; Wydawnictwo Literackie: Cracow, Poland, 2006.

23. Gosk, H. Wychodzenie z "Cienia Imperium". Wattki Postzależnościowe w Literaturze Polskiej XX i XXI Wieku; Universitas: Cracow, Poland, 2015.

24. Gosk, H. Opowieści "Skolonizowanego/Kolonizatora". W Kręgu Studiów Postzależnościowych nad Literatura Polska XX i XXI Wieku; Universitas: Cracow, Poland, 2010.

25. Kostera, M. The Modern Crusade: The Missionaries of Management Come to Eastern Europe. Manag. Learn. 1995, 26, 331-352. [CrossRef]

26. Allen, G. Post Colonialism in Poland: New Markets, New Opportunities and New Cultural Imperialism. J. Manag. Financ. Sci. 2016, 9, 55-76.

27. Balcerowicz, L. Wolność i Rozwój, Ekonomia Wolnego Rynku; Znak: Cracow, Poland, 1995.

28. Stańczyk, Z.J. Konsensus waszyngtoński a reformy w krajach postkomunistycznych. Zesz. Nauk. Pol. Tow. Ekon. 2004, 2, 59-72.

29. Bezrobocie 1990-2010. Available online: https://rynekpracy.pl/monitory/bezrobocie-1990-2010 (accessed on 16 June 2020). 
30. Stiglitz, J.E. Whither Reform? Ten Years of the Transition. In Proceedings of the 1999 Annual Bank Conference on Development Economics, Washington, DC, USA, 28-30 April 1999. Available online: https://www8.gsb.columbia.edu/faculty/jstiglitz/sites/jstiglitz/files/1999_4_Wither_Reform.pdf (accessed on 15 June 2020).

31. Lin, J.Y. The Washington Consensus revisited: A new structural economics perspective. J. Econ. Policy Reform 2014, 18, 96-113. [CrossRef]

32. Lin, J.Y. New Structural Economics. A Framework for Rethinking Development and Policy; The World Bank: Washington, DC, USA, 2012.

33. Hofstede, G. Culture's Consequences: International Differences in Work-related Values; Sage Publications: Beverly Hills, CA, USA, 1980.

34. Hofstede, G.; Bond, M.H. The Confucius connection: From cultural roots to economic growth. Organ. Dyn. 1988, 16, 5-21. [CrossRef]

35. Hofstede, G. Dimensionalizing Cultures: The Hofstede Model in Context. Online Read. Psychol. Cult. $2011,2$. [CrossRef]

36. Minkov, M. Cultural Differences in a Globalizing World; Emerald: Bingley, UK, 2011.

37. Kwek, D. Decolonizing and Re-Presenting Culture's Consequences: A Postcolonial Critique of Cross-Cultural Studies in Management. In Postcolonial Theory and Organizational Analysis: A Critical Engagement; Prasad, A., Ed.; Palgrave: New York, NY, USA, 2003; pp. 160-194.

38. Verdery, K. The Political Lives of Dead Bodies: Reburial and Postsocialist Change; Columbia University Press: New York, NY, USA, 1999.

39. Morgan, A. Dad, do not cry: Imagination and creativity on their own terms in inclusive cities and communities. In Organizing Hope: Narratives for a Better Future; Ericsson, D., Kostera, M., Eds.; Edward Elgar Publishing: Cheltenham, UK; Northampton, MA, USA, 2019; pp. 153-165.

40. Denzin, N.K.; Lincoln, Y.S. Introduction: The Discipline and Practice of Qualitative Research. In The Sage Handbook of Qualitative Research, 4th ed.; Denzin, N.K., Lincoln, Y.S., Eds.; Sage Publications: Thousand Oaks, CA, USA, 2011.

41. Crowe, S.; Cresswell, K.; Robertson, A.; Huby, G.; Avery, A.; Sheikh, A. The case study approach. BMC Med Res. Methodol. 2011, 11, 100. [CrossRef] [PubMed]

42. Majchrzak, S.G. The Gdańsk Shipyard: Production regime and workers' conflicts in the 1970s and 1980s in the People's Republic of Poland. In Shipbuilding and Ship Repair Workers around the World: Case Studies 1950-2010; Varela, R., Murphy, H., Van der Linden, M., Eds.; Amsterdam University Press: Amsterdam, The Netherlands, 2017; pp. 365-396.

43. Katka, K. Stocznia Gdańsk Znowu Stała Się Państwowa. Available online: http://trojmiasto.wyborcza.pl/ trojmiasto/7,35612,23706823,stocznia-gdansk-znowu-stala-sie-panstwowa.html (accessed on 28 April 2020).

44. Rozporzadzenie Prezydenta Polski z dnia 10 grudnia 2018 r. w sprawie uznania za pomnik historii “Gdańsk—Stocznia Gdańska, miejsce narodzin Solidarności”. Dz. Ustaw Rzeczyposp. Pol. 2018, 31, 2506.

45. Holzer, J. Solidarność 1980-1981: Geneza i Historia; Ominpress: Warsaw, Poland, 1990.

46. Terlecki, R. "Solidarność": Dekada Nadziei 1980-1989; Instytut Pamięci Narodowej: Warsaw, Poland, 2010.

47. Woś, R. To Nie Jest Kraj Dla Pracowników; Wydawnictwo WAB: Warsaw, Poland, 2017.

48. Kornai, J. Droga do Wolnej Gospodarki; Fundacja Polska Praca: Warsaw, Poland, 1991.

49. Kozik, A. The Artists' Colony in the Former Gdańsk Shipyard. Balt. Worlds 2018, 1, 4-16. Available online: http://balticworlds.com/wp-content/uploads/2018/06/BW-1-2018-Against-the-Scatter-of-the-World.pdf (accessed on 9 July 2020).

50. Williams, J.C. White Working Class: Overcoming Class Cluelessness in America; Harvard Business Review Press: Boston, MA, USA, 2020.

51. Zając, I. (Academy of Fine Arts, Gdańsk, Poland). Personal communication, 2018, 2019.

52. Zajac, I. Shipyard on Air. Available online: http://www.stoczniaweterze.com (accessed on 4 May 2020).

53. Borkowski, G. Od Muralu Iwony Zając do "Stoczni w Eterze”. Zapis Historii i Historia Zapisu. 2013. Available online: https://archiwum-obieg.u-jazdowski.pl/kronika/28774 (accessed on 3 May 2020).

54. Sagan, I. Młoda demokracja a neoliberalna polityka miejska. Przeglad Socjol. 2016, 65, 9-26.

55. Pietrzak, R.S. Niedopuszczalne Jest Blokowanie Przez ECS i Władze Gdańska Przeniesienia Tablic 21 Postulatów do Sali BHP, 2019 PAP. Available online: https://www.pap.pl/aktualnosci/news\%2C555454\%2Csniedopuszczalne-jest-blokowanie-przez-ecs-i-wladze-gdanska-przeniesienia (accessed on 24 April 2020). 
56. Prawelska-Skrzypek, G. Miasta o Niezharmonizowanym Rozwoju w Świadomości Mieszkańców (na Przykładzie Miast Polskich); Wyd. Uniwersytetu Jagiellońskiego, Rozprawy Habilitacyjne: Cracow, Poland, 1990.

57. Sagan, I. ; Miasto. Nowa Kwestia i Nowa Polityka; Wydawnictwo Naukowe SCHOLAR: Warszawa, Poland, 2017.

58. Budnik, E. Stocznia Schichaua Wpisana do Rejestru Zabytków. Available online: https://www.trojmiasto.pl/ wiadomosci/Stocznia-Schichaua-wpisana-do-rejestru-zabytkow-n141275.html (accessed on 5 May 2020).

59. Decyzja w Sprawie Wpisania do Rejestru Zabytków nr PWKZ.5140.5.2017.AK(PŚ) z Dnia 7 Stycznia 2020 r. Wydana Przez Pomorskiego Wojewódzkiego Konserwatora Zabytków. Available online: https://s-trojmiasto.pl/download/wpis_stocznia.pdf (accessed on 5 May 2020).

60. Prawelska-Skrzypek, G.; Lenatrowicz, M. Badanie organizacji i zarządzania na gruncie humanistyki. Probl. Zarzadzania 2013, 11, 45-57. [CrossRef]

(C) 2020 by the authors. Licensee MDPI, Basel, Switzerland. This article is an open access article distributed under the terms and conditions of the Creative Commons Attribution (CC BY) license (http://creativecommons.org/licenses/by/4.0/). 